\title{
Timur'un Elçisi Sultaniyeli Johannes ve Libellus de Notitia Orbis Adlı Eserinden Bazı Parçalar
}

\author{
The Envoy of Timur Johannes of Sultaniye and Some \\ Fragments from his Work Libellus de Notitia Orbis
}

\begin{abstract}
Altay Tayfun ÖZCAN*
$\ddot{\partial} z$

Niğbolu muharebesinde Haçlı ordusunu hezimete uğratan Yıldırım Bayezid'ın Ankara muharebesinde mağlup olması Avrupa'nın gözlerini birden bire Iran'a çevirdi. Onlar Türk tehlikesini tamamen ortadan kaldırmak için uygun bir ortamın doğduğunu düşünmekle birlikte bunu tek başlarına başaramayacaklarını da biliyorlardı. Bundan ötürü bazı bilgili kimseler arasinda Timur ile ittifak kurulması fikri ortaya çıtktı̆̆ görülmektedir. Clavijo'nun bu amaçla Timur'u ziyaret etmesine bakacak olursak bu, devlet adamların da etkilemişti. Ancak Timur'dan hiçbir olumlu cevap alamadılar. Buna mukabil o, ekonomik ilişkileri canlandırmak niyetiyle Avrupa devletleri ile temas kurmaktan geri durmadl. 1402'de Sultaniye'deki Katolik kilisesinin başında bulunan Johannes'i bu maksatla Avrupa'ya gönderdi. Onun, önce İtalya, ardindan Fransa ve İniltere'den sonra İspanya'da faaliyet gösterdiği görülmektedir. Italya'daki faaliyetlerinin neticesi kaynaklara yansımamışsa da diğer ülkelerden olumlu cevap mektupları almayı başardl. Ancak yolcuğu sırasında Timur'un ölümü ve ardından yaşanan taht mücadelelerinin de etkisiyle cevap mektupların Timurlu sarayına geri götürememişstir. Bu açıdan bakıldığında diplomatik görevi yarım kaldı̆̆ anlaşılmaktadır. Bununla birlikte seyahati sirasinda iki eser kaleme almıştır. Bunlardan birisi Dünya Bilgisi Kitapçığı manasına gelen Libellus de Notitia Orbis adlı eseridir. Yazarın bu eseri kaleme almasındaki asıl amacının doğu ülkelerindeki Hiristiyanlığın durumu hakkında genel bilgiler vermek olduğu anlaşıllyorsa da bunu yaparken verdiği kimi bilgiler kültür ve siyasi tarih açısından da önemlidir. Bu çallşmamızda Johannes'in seyahati ile ilgili bilgiler verdikten sonra eserde yer alan siyasi ve kültür konulartyla ilgili kisımların çevirisini takdim edeceğiz.
\end{abstract}

Anahtar Kelimeler: Timur, Osmanlılar, Avrupa, Haçlılar, Coğrafya.

${ }^{*} Y r d . D o c ̧ . D r .$, Dumlupınar Üniversitesi, Fen-Edebiyat Fakültesi, Tarih Bölümü, Ortaçă̆ $A B D$. 


\begin{abstract}
The rout of Ylldirlm, in the battle of Ankara, who had defeated the crusade in the Niğbolu battle attracted the attention of Europe to Iran. They were thinking that the suitable occasion had emerged to eliminate the threat of Turk completely but, at the same time, they were aware of the fact that they could not do that alone. Therefore, it is seen that the idea of making alliance with Timur had emerged among some intellectuals. If the Clavijo's visit to Timur is taken into consideration, it can be observed that this idea had affected the statesmen too. But they could not draw any positive reply from Timur. But he didn't hesitate to get into touch with European states to improve the economical relations. In 1402, he sent Johannes who was in the charge of the church in Sultaniye to Europe for this purpose. It is seen that he had firstly served in Italy and then in France and after England in Spain. Even if the results of his activities in Italy had not been reflected in the sources, he could take positive responses from other countries. But as a result of the death of Timur during his travel and the struggles for the throne he could not deliver the letters to the Timurid palace. From that perspective, it is seen that his diplomatical duty has mired down. However, he has written two works during his travel. One of them is Libellus de Notitia Orbis which means the Booklet of World Infromation. Even if it is understood that the main aim of the writer, while writing this work, had been to give general informations about the position of Christianity in eastern countries, the informations which he gives while doing that are very important in terms of culture and political history. In this work we will present the translations of political and cultural subjects stated in the work after giving informations about the travel of Johannes.
\end{abstract}

Key Words: Timur, Ottomans, Europe, Crusades, Geography.

Avrupa devletleri 1241-1242 yılını felaketle neticelenen Moğol saldırıları ile geçirmelerine karşın bir taraftan yeni bir Moğol saldırısını önlemek, diğer taraftan da Kudüs'teki idarelerini yeniden kurmak için 1245'lerde Moğollarla ittifak kurmanın yollarını aramaya başlamışlardı. Güyük ve Möngke'nin Büyük Hanlıkları döneminde merkezî Moğol idaresi bu taleplere olumlu yaklaşmamışsa da İran'daki yöneticilerin tutumu farklı olmuştur. Elçigiday Noyan ile başlayan ve Hülegü ile ardıllarının devam ettirdikleri bu süreçte İran'daki Moğol idaresinin, Gazan Han'a kadar Büyük Hanlığa bağlı kalmakla birlikte farklı bir tutum takınmaları Orta Doğu'daki siyasi şartlarla yakından ilgiliydi. Zira onlar, Avrupalılarla ittifak halinde girişecekleri askerî müdahale neticesinde Suriye'de önlerini kesen ve batı sınırları için daimi bir tehlike olan Memlûkları bertaraf edebileceklerini ve böylelikle kuzeyde Altın Orda Hanlığı ve doğuda Çağatay Hanlığı ile daha etkin bir şekilde mücadele ederek bölgedeki konumlarını daha da güçlendirebileceklerini iyi biliyorlardı. Böylesi bir ortam onlara aynı zamanda Çin'den gelen ipek ve sair emtiayı doğrudan Suriye limanlarına 
aktarmalarına ve netice olarak dünya ticaret hayatındaki üstünlüklerini daha da artırmak imkânını sağlayacaktı. Bu hususlar, Avrupalılarla ittifakının İran Moğolları için hayatî bir mesele olduğunu göstermektedir. Ancak tarafların tüm samimiyetine karşın ilișkiler, birkaç müdahale hariç, hiçbir askerî netice vermedi ${ }^{1}$. Bununla birlikte Avrupalı elçilerin Moğol ordasına ulaşmak yolunda harcadığı çabalara, tüccar ve din adamlarının seyahatleri de eklenince Avrupalı entelektüeller, daha önce varlığından öte bir şey bilmediği engin bir coğrafya ile karşı karşıya kaldılar. Bu değiş̧im, Avrupa coğrafyacılığında büyük bir devrimdi ${ }^{2}$. Benzer bir husus, Avrupa uluslar arası siyaset tarzı ve metodu için de geçerlidir. Artık Avrupa siyasetinde sınırlı bir metod olarak kullanılagelmiş "düşmanın ötesindeki dost", Ortadoğu politikalarında temel bir politik yaklaşıma dönüştü. İşte XV. yüzyıla gelindiğinde Timur'un Batılı devlet adamlarınca olası bir müttefik olarak görülmesinde bu tarihi geçmişin büyük bir etkisi bulunuyordu. Ancak ittifak yolunu aradıkları hükümdar, daha önce hiçbir İlhanlı hükümdarının sahip olamadığı kadar büyük bir gücü elinde bulundurarak Batının askerî yardımına ihtiyacı bulunmuyordu. Nitekim basit ve kimi tarihî şartları göz

\footnotetext{
${ }^{1}$ Konu ile ilgili olarak geniş bir bibliyografya sunmak mümkünse de şu çalışmalar önemlidir. Bk. J. Richard, "Le Debut des Relations entre la Papaute et les Mongols de Perse", Journal Asiatique, 137/1949, s.291-297; L. Lockhart, "The Relations Between Edward I and Edward II of England and the Mongol Il-khans of Persia", Iran, Vol.6, s.23-31; S. Schein, "Gesta Dei per Mongolos 1300”, The English Historical Review, Vol.94/373, s.805-819; A. Barany, "The Last Crucesignatus Edward I and the Mongol Alliance", Annual of Medieval Studies at Central European University, Vol.16, s.1-22; J. Paviot, "England and the Mongols (12601330)", Journal of the Royal Asiatic Society, Vol.10/No.3, Nov. 2000, ss. 305-318.; D. Aigle, "The Letters of Eljigidei, Hülegü and Abaqa: Mongol Overtures or Christian Venteiloquism?", Inner Asia, 7/2005, s. 143-162; A. Yuval1, Ilhanlılar Tarihi I: Kuruluş Devri, Erciyes Üniversitesi yay., Kayseri, 1994, s.174-181. Avrupa-İlhanlı ittifakının Memlûklar tarafindan nasıl değerlendirildiğine ilişkin olarak bk. R. Amitai, "Mamluk Perceptions of the Mongol-Frankish Rapprochement", Mediterrranean Historical Review, Vol.VII/I, s.50-65; C. Kanat, "Baybars Zamanında Memlûk-İlhanlı Münasebetleri", Tarih Incelemeleri Dergisi, S.XVI/2001, s.31vd.

2 Bugün artık Avrupalı tarihçilerin neredeyse tamamında, Moğol işgalinin Avrupa'daki coğrafya bilgisini genişlettiğine ilişkin genel bir kanı vardır. Gerçekten de, Doğu'ya dair bilgilerin Eskiçağ'daki seviyesinin Ortaçağ'da azalmasına karşın Moğol işgaliyle birlikte yazarlar Doğu'ya dair bilgilerini daha da geliştirdiler. Mesela XIV. yüzyılda standart bir Avrupalı bilgin Çin'i bundan bir yüzyıl öncesine oranla daha iyi bildiği gibi, yanlış bilinen kimi coğrafî bilgileri tashih ediyor, eskiden bilinemeyen pek çok ada ve burada yaşayan halkların gelenek ve görenekleri hakkında bilgiye daha kolay ulaşıyordu. XV. yüzyılın sonlarına gelindiğinde Çin'deki Büyük Han'a ulaşmak isteyen Christoph Colombus'un aklındaki dünya, işte böyle bir dünya idi. Bu coğrafi değişim ve neticelerine dair bk. Bk. C.R. Beazley, The Dawn of Modern Geography, Vol. III, Oxford, 1906; J.L. Abu-Lughot, Before European Hegemony The World System AD. 1250-1350, Oxford University Press, 1989, s. 154 vd.; A. Hamdani, "Colombus and the Recovery of Jarusalem", Journal of the American Oriental Society, Vol.99/1, 1979, s.39-48.
} 
ardı eden bir karşılaştırma yapacak olursak Timur, İlhanlıların siyasi üstünlük kuramadığı Derbend ve Fırat hattının doğusuna kolaylıkla hâkim olmuş ve buraların sahiplerine boyun eğdirmeyi başarmışt ${ }^{3}$.

Latince kaynaklarda Timur ile ilgili ilk kayitlar, kendisine dair olumsuz bir bakış açısı içerisinde kaleme alınmıştır. $\mathrm{Bu}$, Kefe, Gürcistan ve Ortadoğu'daki faaliyetlerinde Hıristiyanların da zarar görmesiyle yakından alakalıyd ${ }^{4}$. Ancak, Timur'un Haçlı ordularını 1396'da ağır bir yenilgiye uğratan ve bundan ötürü Avrupa'da umumi bir nefretin hedefi olan Yıldırım Bayezid'1 Ankara'da yenmesi ve esir etmesiyle bu görüş birden bire değişti. Zafer, Avrupa'nın değişik ülkelerinde ortak bir heyecan ve memnuniyetle karşılanmış ${ }^{5}$, birkaç yıl öncesine kadar kendisinden öfke ve korkuyla bahsedilen Timur, Hıristiyanlığın öcünü alan bir kimse olarak tasvir edilmeye başlanmıştır ${ }^{6}$. Onun, Bayezid'ı zincire vurduğu, kafeste tuttuğu ve diyar diyar gezdirdiği haberleri ${ }^{7}$ Ankara muharebesinden sonraki umumî havayı şenlendirmek için zikredilirken, daha cüretkâr fikirlere sahip bir takım kimseler, Niğbolu'da kaybettikleri prestiji ${ }^{8}$ yeniden sağlamak adına Türklere karşı yeni bir Haçlı seferi ilan etmeyi tasarlıyorlardı. Onlara göre

3 İ. Aka, Timur ve Devleti, TTK yay., Ankara, 2000, s.20-22; H. Alan, Bozkırdan Cennet Bahçesine Timurlular 1360-1506, Ötüken yay., İstanbul, 2007, s.78.

${ }^{4}$ P. Jackson, The Mongols and the West 1221-1410, Harlow, 2005, s.240, 241.

${ }^{5}$ M. Meserve, Türk, çev. M.T. Akad, April yay., İstanbul, 2011, s.439.

6 A. Knobner, "Timur'un Yükselişi ve Batı'nın Diplomatik Cevabı", çev. M.Ş. Yüksel, Türkiyat Araştırmaları Dergisi, S.18/2005, s.232, 237, 240. Benzer mütalaalar Doğu Romalı yazarlar tarafindan da yapılmıştır. Bk. M. Daş, "Bizans Kaynaklarında Timur İmajı", Tarih Incelemeleri Dergisi, C.XX, S.2, Aralık 2005, s.49, 50.

${ }^{7}$ M. Meserve, a.g.e., s.439. Eserini XV. yüzyılın ikinci çeyreğinde kaleme alınan Redisio'nun bu tip meselelere ziyadesiyle önem verdiği görülmektedir. Bunlardan birisine göre Timur, Bayezid'1 esir ettiğinde kendisine Canis ex genere canum, habuisti animum contra nostram arma sumere? yani It oğlu it, bizim kuvvetimize karşl durmaya nasıl olur da cüret edersin? demiştir (Meserve bunu küfürle karışık çevirmiştir, ancak tam çevirisi yukarıdaki gibidir). Bk. M. Meserve, a.g.e., s.448, 495/22.dp. Bununla birlikte Timurlu kaynakları Bayezid'e iyi muamelede bulunulduğunu ifadeyle daha farklı bilgiler verir. Bk. Nizamüddin Şâmî, Zafernâme, çev. N. Lugal, TTK yay., Ankara, 1987, s.310, 311, 322; Caferî b. Muhammed el Hüseynî, Târîh-i Kebîr (Tevârih-i Enbiyâ ve Mülûk), çev. İ. Aka, TTK yay., Ankara, 2011, s.31, 33, 34. Benzer bilgiler Osmanlı kaynaklarında da bulunur. Bk. F.M. Emecen, "İlk Osmanlı Kroniklerinde Timur İmajı”, Prof.Dr. İsmail Aka Armağanı, İzmir, 1999, s.30, 33.

${ }^{8}$ Ortaya çıkan bu psikolojiyi iyi şekilde ortaya koyan kaynaklardan birisi St. Denis kroniğidir. Burada yer alan bilgiler M. Daş tarafindan incelenmiş ve değerlendirilmiştir. Bk. M. Daş, "Saint-Denis Ruhbanının Kroniği Adlı Fransız Kaynağına Göre Niğbolu Savaşı", Tarih Incelemeleri Dergisi, C.XXVII/1, 2012, s.69-77. Niğbolu muharebesinin yarattığı etki diğer kaynakların da kullanımı ile K. DeVries tarafindan tetkik edilmiştir. Bk. K. DeVries, "The Effect of Killing the Christian Prisoners at the Battle of Nicopolis", Crusaders, Condottieri and Connon Medieval Warfare in Societies around the Mediterranean, ed. L.J. A. Villalon, D.J. Kagay, Brill Publishing, 2002, s.157-172. 
Timur, Hıristiyanlara gaddarca davranan Müslümanlara karşı Tanrı tarafından gönderilen ilahi bir kamçıydı. Böyle düşünenlerden biri olan Jacopo Delatio, Timur'un tarih sahnesindeki varlığını ilahî adalete bağlayarak ${ }^{9}$ döneminin ve kültür çevresinin bakış açısını aksettirir. Benzer değerlendirmeler ilerleyen y1llardaki kroniklerde de bulunur ${ }^{10}$.

Osmanlılar üzerine Timur ile ortaklaşa düzenlenmesi planlanan Haçlı seferi, Clavijo'nun da bu maksatla görevlendirilmesine bakacak olursak epey ciddi bir tasarı haline gelmişti. Buna mukabil İspanyol elçi, Timurlu sarayından herhangi bir cevap alamadan ülkesine dönmek mecburiyetinde kaldı. Bu başarısızlık, A. Knobner tarafından, Timur'un Çin seferine girişme niyetine bağlanarak, Timur'un yeni bir Anadolu seferi düzenlemek istememesiyle izah edilmiştir ${ }^{11}$. Oysaki Timur'un daha önce Fransız kralı V. Charles'a gönderdiği mektuplarında askerî ittifaka değinmemesi, müşterek bir askerî harekâta Anadolu'da iken dahi itibar etmediğini gösterir ${ }^{12}$.

Timur'un Batılı devletlerle kurmaya çalıştı̆g diplomatik ilişkilerin ana nedeni ekonomik menfaatlerdi. Nitekim Timurlu sarayından Fransa kralı VI. Charles'a gönderilen üç mektup, bu niyeti açık şekilde gösterir. Timur, I. mektubunda, kendi tüccarları ile Fransız tüccarlarının her iki tarafin ülkelerinde de serbest bir şekilde ticaret yapmalarını istediğini ifade etmiştir. Hatta mektubun bir yerinde "quia mundus per mercatores prosperatur", yani "çünkü dünya tüccarlar sayesinde refaha erer" sözleriyle ticarete verdiği öneme veciz bir vurgu yapar ${ }^{13}$. II. mektubunda ise "Avrupa'nın düşmanı" olan Bayezid'a karşı sağladığı üstünlükten bahsettikten sonra, Fransa kralı ve kendi şanının ülkedeki tüccarlara bağlı olduğunu dile getirir ${ }^{14}$. Timur'un oğlu Miranşah'ın mektubunda da, dinler arasında farklılığa rağmen tüccarlardan ötürü ilişkilerin korunmasının gerekliliğine vurgu yapılır ${ }^{15}$.

\footnotetext{
${ }^{9}$ M. Meserve, a.g.e., s.442, 443.

${ }^{10}$ M. Meserve, s.448, $457 \mathrm{vd}$.

${ }^{11}$ A. Knobner, a.g.m, s.239, 240.

12 Bununla birlikte Timur, Ankara muharebesi öncesinde Doğu Roma İmparatorluğu ve Trabzon Krallığı ile temas kurarak Yıldırım Bayezid ile mücadelesinde destek istemiştir. Bk. İ.İ. Umnyakov, "Vneşnepolitiçeskie Svyazi Samarkanda s Gosudarstvami Zapadnoy Evropı", Ístoriya Samarkanda, red. İ.M. Muminov, Taşkent 1969, s.175, 176.

${ }^{13}$ S. de Sacy, "Memoire sur Une Correspondance Inedite de Tamerlan avec Charles VI", Memoires de L'Institut Royal de France Academie des Inscriptions et Belles-Lettres, Tome VI/1822, s.474. Buradaki ifadelerle ilgili olarak ayrica bk. İ. Aka, a.g.e., s.128; İ. Aka, "Timur Sadece bir Asker mi idi?", Makaleler, C.II, haz. E.S. Yalçın, Ş. Gedikli, Berikan yay., Ankara, 2005, s.115.

${ }_{14}$ Ut vestrae et nostrae magnificentiae cedat ubique ad nominis laudem et patriae mercatorum utilitatem. Bk. S. de Sacy, a.g.m, s.479.

${ }^{15}$ Et si inter nos est differentia fidei tamen in hoc mundo amorem salvare debemus propter utilitatem multorum et specialiter mercatorum. Bk. S. de Sacy, a.g.m, s.480.
} 
Timur'un Batılılarla temaslarında ticaretin ana mevzu olarak karşımıza çıkması, ticarete verdiği önemden ileri geliyordu. Bu husus, Timur'un, başkentini dünyanın en müreffeh kentlerinden biri yapmak için ticareti teşvik ettiğini fark eden İspanyol elçi Clavio'nun gözünden de kaçmamıştır ${ }^{16}$.

Timur'un Batılı devletlerle ilişkilerindeki duruşunu göstermesi açısından önemli olan bu mektuplarda ilgi çekici bir diğer husus, Batı dünyası ile ilgili konularda Timur'u bilgilendirdiği ifade edilen Johannes adlı bir kişiden bahsedilmesidir. Doğunun piskoposu namıla zikredilen bu din adamı, zamanında İran ve çevresindeki bölgenin kilise hiyerarşisindeki en yüksek din adamı makamını ifade eden Sultaniye arhiepiskoposu olarak bulunuyordu. Kendisinden Johannes de Sulthanieh yani Sultaniyeli Johannes olarak bahsedilmesi de bu görevi ile alâkalıdır.

Sultaniyeli Johannes karşımıza ilk olarak 26 Ağustos 1398'de Sultaniye arhiepiskoposluğuna tayin edilmesiyle ilgili bir belgede çıkar ${ }^{17}$. Sultaniye'deki faaliyetleri kaynaklarımıza yansımamışsa da, Timur'un sarayından Fransa kralına gönderilen mektuplarda dinî görevinin yanında Timur'a Batı ile ilgili konularda bilgi veren bir kimse olduğu anlaşılmaktadır. Bu görevi ne zamandan itibaren yürüttüğü bilinmemektedir. Ancak Johannes ile arkadaşlığı bilinen Niemli Dietrich adlı bir din adamının 1410 'da "çok yakın bir arkadaşı olan Katolik piskoposun" Timur ile 12 y1lı aşkın bir zaman geçirdiğinden bahsetmesine ${ }^{18}$ bakacak olursak Johannes, Timur'un yanından 1402'de ayrıldığından 1390'dan itibaren Timurlu sarayına yakın bir kimse olduğunu söylemek mümkündür.

Johannes'in Timurlu sarayı ile doğrudan temas halinde olduğunu gösterir ilk bilgi, 1398 'de Timur'un elçisi olarak İtalya'da bulunmasına ilişkindir ${ }^{19}$.

\footnotetext{
${ }^{16}$ İ. Aka, a.g.e., s.128. Timurlularda ticari faaliyetler ve kent hayatındaki önemine dair bk. İ. Aka, a.g.e., s.128-133; R. Ferrier, "Trade from the Mid 14th Century to the End of the Safavid Period", The Cambridge History of Iran, Ed. P. Jackson, Cambridge UP, 2006, ss.413-420.

${ }^{17}$ L. Lockhard, "European Contacts with Persia 1350-1737”, Cambridge History of Iran, ed. P. Jackson, L. Lockhart, Cambridge UP, 2006, s.375; L. Tardy, "The Caucasian Peoples and Their Neighbours in 1404”, Acta Orientalia, Tomus XXXII,/1, 1978, s.84. 1377'de Nahçivan piskoposluğuna tayin edilen Johannes de Galonifontibus adlı kişinin Sultaniyeli Johannes'in eski adı olduğu bazı bilim adamları tarafından kabul edilmişse de, daha önceki bazı çalışmalarda ikisinin farklı kişiler olduğu yönünde ciddi itirazlar yapılmıştı. Tartışmalar için bk. A. Luttrell, a.g.m, s.211. Biz geçmişte yapılmış bu itirazların geçerli olduğunu düşünüyoruz.

${ }^{18}$ A. Luttrell, a.g.m, s.212.

${ }^{19}$ Yukarıda ifade ettiğimiz Timur'un mektubunda Johannes'in elçi olarak gönderildiği ifade ediliyorsa da nereye ve ne zaman gönderildiğinden bahsedilmez. Bk. S. de Sacy, a.g.m, s.474. Ancak Miranşah'ın mektubunda Johannes'in Venedik ve Cenova'ya gönderildiği dile
} 
1401 'de ise Timurlu sarayında bulunduğu anlaşılmaktadır ${ }^{20}$. Zira yazar, metin içerisinde görüleceği üzere, Bayezid'ın elçilerinin Timur'un huzuruna geldiğinde kendisinin de orada olduğunu belirtir. Johannes 1402'de Timur'un ordusuyla birlikte Anadolu'ya gitmiștir. Bununla birlikte Ankara muharebesine iştirak etmemiştir ${ }^{21}$. Johannes' in Timurlu sarayına bu kadar yakın bir kimse olmasına karşın öyle görünüyor ki Timur ile ilişkisi resmî kalmıştır ${ }^{22}$. Johannes'in Timur ile ilgili neredeyse hiçbir karakter tahliline girişmemesi bize bunu göstermeye yeterlidir. Buna karşın herhalde Miranşah'a daha yakın bir kimseydi ${ }^{23}$. Aralarındaki temasın ne zaman başladığı tam olarak belli değilse de bunun Miranşah'1n 1393'te Sultaniye'yi

getirilir. Bk. S. de Sacy, a.g.m, s.479. Bunun 1398'de olduğu anlaş1lıyor. Zira Johannes'in bu sırada Roma'da olduğunu gösterir deliller vardır. Bk. A. Luttrell, a.g.m, s.211.

${ }^{20}$ A. Luttrell, a.g.m, s.215.

${ }^{21}$ Kimliği ifade edilmemişse de Timur'un Fransa kralına gönderdiği 1 Ağustos 1402 tarihli mektubun Latince çevirmeni eğer Johannes ise, mektubun Sivas yakınlarında yazıldığı ifade edildiğinden, Ankara ile Sivas arasındaki uzaklık ve dönemin ulaşım şartları göz önüne alındığında muharebeye katılan bir kişinin, eğer ulak değilse, birkaç gün içinde Ankara'dan Sivas'a varabilmesi mümkün değildir. Bu bize onun muharebeye iştirak etmediğini gösterir. A. Luttrel ise Johannes'in Ankara muharebesine katıldı̆̆ını ifade eder. Bk. A. Luttrell, a.g.m, s. 215 .

${ }^{22}$ B.F. Manz'ın değerlendirmesine de bk. B.F. Manz, “Timur ve Hâkimiyetin Sembolü”, çev. M.Ş. Yüksel, Tarih İncelemeleri Dergisi, Vol. XV/2000, s.260.

${ }^{23}$ Eserinde Etiyopya ile ilgili bilgiler verirken Miranşah'ın Hıristiyanlara dinî açıdan hürriyet sağladığından memnuniyetle bahsederken Chronographia Regum Francorum'a girmiş ifadelerinde de Miranşah ile ilgili aynı tasviri tekrarlar. Bk. Chronographia Regum Francorum, T.III, Paris 1897, s.213. Ayrıca bk. A. Luttrel, a.g.m, s.218. Miranşah'ın Hıristiyanlara karşı hoşgörülü tavrı Metsoplu Toma'nın tarihinde de yer alır. Bk. Toma Metsopski, Timurlenk ve Haleflerinin Tarihi, çev. G. Solmaz, Elips yay., Ankara, 2009, s.26, 27. Miranşah ile ilgili bu yorumları Johannes'in, Timur'dan sonra tahta onun çıkmasını arzuladığı şeklinde değerlendirilmiştir. Bk. A. Luttrell, a.g.m, s.218. Eğer bu görüşte haklılık payı varsa, Johannes herhalde Miranşah'ın tahta çıkması durumunda Timurluların Bati ile ilişsilerinin daha samimi bir noktaya gelmesi için bir propaganda halindeydi. Maksadı her ne olursa olsun, Miranşah'ın tutumu Avrupa'da olumlu bir şekilde karşılandı. Nitekim İngiltere Kralı IV. Henry'nin Timurlu sarayına gönderdiği mektubunda Miranşah'a Hıristiyanlara karşı iyi davrandığından ötürü teşekkür edilmiştir. Bk. A. Luttrell, a.g.m, s.221. Oysaki Miranşah'ın konumu hiç de Johannes'in ümit ettiği bir geleceği vaat etmiyordu. Zira mektubun kaleme alınmasından birkaç yıl önce bazı davranışlarından ötürü babası ile arası açılmıştı ve taht için muhtemel adaylar arasında düşünülmüyordu. Bk. İ. Aka, Mirza Şahruh ve Zamanı, TTK yay., Ankara 1994, s.21, 22; İ. Aka, Timur ve Devleti, s.23, 25; B.F. Manz, Timurlenk, çev. Z. Bilgin, Kitap yay., İstanbul, 2006, s.101. Miranşah'ın bir cariyeden dünyaya gelmesi taht adaylığı için ciddi bir engeldi. Bundan ötürü yaşayan en büyük evlat olmasına rağmen Timur veliaht olarak Cihangir'in oğlu Muhammed Sultan'1 tercih etmiştir. Bk. J.E. Woods, “Turco Iranica II", Journal of Near Eastern Studies, Vol.43/No.4, Oct 1984, s.333. Miranşah ile Johannes arasındaki ilişkilerle ilgili A. Luttrell ve B.F. Manz'ın değerlendirmelerine de bk. A. Luttrel, a.g.m, s.218; B.F. Manz, "Timur ve Hâkimiyetin Sembolü”, s.260. 
de içine alan bölgenin valiliğine getirilmesinden sonra $^{24}$ olduğu düşünülebilir.

Daha önce 1398'de elçi olarak Cenova ve Venedik'e gönderilmiş olan Sultaniyeli Johannes, 1402 Ağustosunda yeni bir elçilikle daha görevlendirilince, hayatında yeni bir safha başlıyordu. Beraberinde taşıdığ 1 ikisi Timur'a biri ise Miranşah'a ait olan fermanlardan ilki 1 Ağustos 1402 tarihli olup Ankara muharebesinden hemen sonra yazılmışıır ${ }^{25}$. Farsça metinde, ki üç fermandan sadece bunun Farsçası günümüze erişebilmiştir, nerede yazıldığı ifade edilmemişse de Latince nüshada Sivas yakınlarında yazıldığı kaydedilmiştir. 1 Ağustos tarihi, Farsça metnin yazılış tarihi değil, metnin Latinceye çevrilmiş olduğu tarih olmalıdır. Zira mektup Timur'un diğer ülkelere gönderdiği zafernâmelere benzer bir üslupta kaleme alınmamışıı' ${ }^{26}$.

Johannes'in Sivas'tan ne zaman ayrıldığı bilinmemektedir. Muhtemelen Ağustos ayı içinde yola çıkan din adamı önce İstanbul'a, 1402'nin sonları veya 1403'ün başlarında Venedik'e, ardından da Mart veya Nisan 1403'te Cenova'ya geldi. Bu arada bir süre Roma ve Milano'da da kald12 ${ }^{27}$. Venedik'te bulunduğu sırada Dominiken din adamlarının doğuya gitmelerinin teşvik edilmesini de içeren bir takım dinî temaslarda bulunduğu görülüyorsa $\mathrm{da}^{28}$, İtalya'ya asıl geliş nedeni, Fransa kralına gönderilen fermanların benzerlerinin Cenova ve Venedik hâkimlerine sunulmasıyla ilgili olmalıdır. İtalyan arşivlerinde bunu doğrulayan bir kayıt henüz bulunmamışsa da Timur'un Fransa, İngiltere ve İspanya ile ticari ilişkiler kurmaya çalışırken Akdeniz ticaretinde çok önemli yere sahip İtalyan kent devletlerini göz ardı etmesi mümkün görünmemektedir.

İtalya'da birkaç ay geçiren Sultaniyeli Johannes Mayıs 1403'te Paris'e geldi $^{29}$. Fransa kralı tarafindan kabul edildi ve beraberindeki mektupları sundu. VI. Charles'ın cevabî yazısının Timur'un ve oğlu Miranşah'ın

${ }^{24}$ Clavijo, Embassy to Tamerlane 1403-1406, tr. G. de Strange, London-New York 2005, s.86. Ayrica bk. B.F. Manz, "Miranshah b. Timur”, Encyclopedia of Islam 2, V.VII, LeidenNew York 1993, s.105.

${ }^{25}$ A. Luttrell, a.g.m, s.216.

${ }^{26}$ Timur'un Emirzâde Ömer'e yazdığı zafernâme İ. Aka tarafından neşredilmiştir. Bk. İ. Aka, “Timur'un Ankara Savaşı (1402) Fetihnâmesi”, Makaleler, C.I, haz. E.S. Yalçın, Ş. Gedikli, Berikan yay., Ankara, 2005, ss.133-170. Böylesi bir zafernâme öyle gözüküyor ki Avrupa'da sadece Kastilya kralına gönderilmiştir. Bk. A. Luttrel, a.g.m., s.218.

${ }^{27}$ A. Luttrell, a.g.m, s.219, 220. L. Tardy ise Johannes'in önce Cenova'ya ardından da Venedik'e gittiğini yazar. Bk. L. Tardy, a.g.m., s.85. Ancak A. Luttrell'in tespit ettiği bir mektup Johannes'in önce Venedik'e geldiğini gösterir.

${ }^{28}$ A. Luttrel, a.g.m, s.220.

${ }^{29}$ L. Tardy, a.g.m., s.85; A. Luttrell, a.g.m, s.220. 
isteklerine uygunluk göstermesi ${ }^{30}$, ziyaretin Fransa sarayında memnuniyetle karşılandığını gösterir. Burada bulunduğu zaman zarfında Ankara muharebesi ve Timur ile ilgili bilgiler verdiği gibi bir kitapçık da kaleme ald $^{31}$ ki Chronica Rerum Francorum adlı Fransız kroniğinde Ankara muharebesine ilişkin bilgilerin menşei bu eser olsa gerektir.

Sultaniyeli Johannes, Fransa Kralı'nın 15 Haziran 1403 tarihli cevap yazısını aldıktan sonra Aragon'a doğru yola çıtı. Muhtemelen Fransa Kralına sunduğu mektupların benzerini Kral Martin'e de sundu ve 1 Nisan 1404'te kralın cevap yazısını alarak Almanya'ya yöneldi. Buradaki faaliyetleri belirsizse de Libellus de Notitia Orbis (Dünya Bilgisi Kitapçığı) adlı eserini Almanya' da kaleme almıştır' ${ }^{32}$. 1406'da ise İngiltere'ye gitti. Buradaki amacı da yine ticari ilişkileri geliştirmekti. İngiltere arşivlerinde Timur'un gönderdiği herhangi bir mektup bulunmuyorsa da, IV. Henry'nin cevap metninin VI. Charles'ın cevabî metni ile benzerlik göstermesi, İngiltere kralına da Fransa kralına gönderilen mektubun bir suretinin gönderildiğine işaret etmektedir. Ancak VI. Charles'dan farklı olarak IV. Henry, mektubunda Timur'a Hiristiyanlığı kabul etmesini tavsiye ederken Miranşah'a da Hıristiyanlara ve tüccarlara gösterdiği yardım severlikten ötürü teşekkür ediyordu ${ }^{33}$.

Timur'un elçisi 1406 y1lı içinde İngiltere'den ayrılarak ve Prusya'ya gitti. Ocak 1407'de Marienburg'da bir Töton tarikatı misafir evinde kalan Johannes bir süre sonra Töton tarikatı üstadı Konrad von Jungingen ile görüştü. Üstadın arşivinde ona doğu meseleleri hakkında pek çok bilgi verdiği ifade edilmişse de anlattıklarının mahiyeti kaydedilmemiştir ${ }^{34}$. Bu dönemde Töton hakimiyeteindeki toprakların Deşt-i Kıpçak ile ticari ilişki içerisinde bulunmasın ${ }^{35}$ dikkate alacak olursak Johannes'in ziyaretinin yine iktisadî meselelerle ilgili olduğu düşünülebilir.

Artık diplomatik temaslarını sonlandırdığı anlaşılan Johannes'in, Prusya üzerinden Dnyepr veya Dnyester 1rmağına gelerek buradan Timurlu ülkesine geçmek için İstanbul veya Trabzon'a gitmesi beklenirken o, 13 Haziran 1407 'de tekrar Venedik'e gitti ve 1408 yazına kadar burada kaldı. Onun İtalya'ya gitmesi muhtemelen Timur'un öldügünü ve ardından Miranşah'ın durumunu haber alarak misyonunun artık suya düştügüunü düşünmesinden

${ }^{30}$ S. de Sacy, a.g.m, s.522.

${ }^{31}$ A. Luttrell, a.g.m, s.220, 221.

${ }^{32}$ A. Luttrel, a.g.m, s.221.

${ }^{33}$ A. Luttrell, a.g.m, s.221.

${ }^{34}$ Latince metin A. Luttrell tarafindan aktarılmıştır. Bk. A. Luttrell, s.222.

${ }^{35}$ M. Malowist, "The Baltic and the Black Sea in Medieval Trade", Baltic and Scandinavian Countries, Vol.3/1937, s.39, 40. 
ileri geliyordu ${ }^{36}$. Nitekim bundan sonra da İtalya'daki faaliyetlerine devam etti.

Bir süre sonra Pisa'da bulunduğunu gördügümüz Johannes'in ${ }^{37}, 18$ Eylül 1409 'da Piza konsülü tarafindan İstanbul'a elçi olarak gönderilmesine karar verildi ve 2 Nisan 1409 'daki dönüşüne kadar bu işlerle meşgul oldu ${ }^{38}$. Bu tarihten sonra Piza'da 1409 yılında büyük şizmayı ortadan kaldırmak için toplanan konsül iştirakçileri arasında onun adı da kayıtlıdır ${ }^{39}$. Pisa'daki faaliyetlerinin ardından bir süre Macaristan ve Valaçya sınırlarında ne maksatlı olduğu anlaşılamayan ziyaretinin ardından Aralık 1410'da yeniden İtalya'ya, Bologna'ya döndü. Kısa bir süre sonra da Cambaliensis arhiepiskoposluğuna atandı. Buras1 A. Luttrel tarafindan Pekin olarak değerlendirilmişse de, Cambaliensis ile Kefe'deki Cimbaliensis arhiepiskoposluğunun karıştırıldığı, dolayısıyla da Johannes'in Kırım'daki dinî merkezin başına atandığı anlaşılmaktadır ${ }^{40} .12$ Şubat 1412'de Lvov'da Papalık temsilcisi olduğuna ilişkin kayıtlar ise onunla ilgili son bilgileri teşkil eder ${ }^{41}$.

Böylesine ilgi çekici ve hareketli bir hayat geçiren Johannes'in diplomatik temasları, bir netice vermemişse de günümüze ondan iki eser kalmıştır. Bunlardan birisi Fransa'da Timur ile ilgili olarak verdiği bilgilerin kaydedilmiş olduğu Chronographia Regum Francorum'daki kayitlardır. Bir diğeri ise Libellus (Brevis) de Notitia Orbis (Dünya Bilgisine İlişkin Kitapçık) adlı eseridir. Bu çalışmayı bilim âlemine duyuran kişi Graz'daki el yazması üzerine çalışmış olan A. Kern'dir ${ }^{42}$. L. Tardy ise, eserin Kafkasya ile ilgili kısımlarını kapsayan incelemesinde söz konusu kısımların İngilizce çevirilerini, Latince edisyonu olmaksızın yayımlamıştır ${ }^{43}$.

${ }^{36}$ Timur'un ardından yaşanan gelişmelerle ilgili olarak bk. İ. Aka, "Timur'un Ölümünden Sonra Doğu Anadolu, Azerbaycan ve Irak-1 Acem'de Hâkimiyet Mücadeleleri”, Türk Kültürü Araştırmaları, XXI/1-2, 1984, ss.49-66.

${ }^{37}$ L. Tardy, a.g.m., s.85; A. Luttrell, a.g.m, s.223.

${ }^{38}$ A.Luttrell, a.g.m, s.223.

${ }^{39}$ H. Millet, "Les peres du Concile de Pise (1409)", Melanges de l'Ecole Française de Rome, T.93/N.2, 1981, s.730. A. Luttrell bu tarihten sonra Sultaniye'deki makamından istifa ettiğini ifade eder. Bk. A. Luttrell, a.g.m, s.224. Ancak ilerleyen yıllarda makam namını kullanması, ki bu konu yazar tarafindan eski namını kullanmaya devam ettiği şeklinde değerlendirilmiştir, yazarın iddiasını şüpheli hale getirir.

${ }^{40} \mathrm{Bu}$ konuda A. Luttrel'in son derece ikna edici deliller ileri sürmesine karşın Johannes'in 1412'de Lvov'da bulunması Kırım'daki makama atanmasından başka bir hususla izah edilemez. Bu konudaki tartışmalar için bk. A. Luttrell, a.g.m, s.225.

${ }^{41}$ A. Luttrell, a.g.m, s.225.

42 A. Kern, "Der 'Libellus de Notitia Orbis' Iohannes III (De Galonifontibus) O.P. Erzbischofs von Sulthanyeh", Archivum Fratrum Praedicatorum, Vol. VIII/1938, ss.82-123.

${ }^{43}$ L. Tardy, a.g.m, 83-111. 
Libellus de Notitia Orbis genel olarak Johannes'in bir şekilde ilişkide olduğu diyarların genel bir tanıtımından ibarettir. Bununla birlikte yazar, bahsini ettiği ülkelerdeki Katolik kiliselerinden ve durumlarına da değinir. Hatta kimi kısımlarda bu bilgilerin büyük bir hâkimiyeti görünür. Bunda Papalık kurumunun ve bu meselelere önem veren kimselerin dikkatlerini Doğu'daki misyonun zayıflığı ile içinde bulunduğu kötü koșullara yönlendirmek gayesi hissedilir ${ }^{44}$. Bunun yanında eserinde, Avrupa'daki dinî meselelere yaklaşımını da göstermekten geri kalmaz. Bayezid'ın, Büyük Şizma adı verilen iki Papalı yapının Türklerin yararına olduğuna ilişkin muhtemelen bizzat yazar tarafindan politik bir gayeyle tasanan- sözünü kaydetmesi, bu niyet içerisinde yazılmış olmalıdır ${ }^{45}$. Ancak bu bilgiler bir kenara bırakılacak olunursa Libellus, XV. yüzyılın ilk yarısında Kafkaslar, İran, Deşt-i Kıpçak'daki halkların durumları, gelenek ve görenekleri ile hangi dine mensup oldukları gibi, genel ve bazı açılardan ilk kültürel antropolojik bilgileri ihtiva eder. Burada ayrıca Timur'un seferlerine ilişkin hususlar da dile getirilir. Mesela Gürcistan ile ilgili kısımda Timur'un, kralı ve ailesini nasıl esir aldığı, ülkesini ne boyutta tarumar ettiği, Azak'a nasıl bir felaket getirdiği gibi konular önemli birer not olarak değerlendirilebilir.

Eserde Johannes'in Timur'a bakış açısını yansıtan ipuçları da kendini gösterir. $\mathrm{Bu}$ konuda Timur'un ortaya çıkışına yorduğu kimi apokaliptik bilgileri ${ }^{46}$ dile getirir. Verdiği bu bilgilere göre Johannes aslında Timur'un ortaya çıkışını değiştirilemez bir kader olarak değerlendirmiştir. Ancak apokaliptik bilgilerin kullanıldığı diğer metinlerden farklı olarak Timur, Gog ve Mogogların soyundan gelip dünyanın sonunda ortaya çıkarak yeryüzünü mahvedecek bir ırkın ahfadı olarak değerlendirilmez. Aksine Tiran yorumu hariç hiçbir olumsuz değerlendirmede bulunmaz. Hatta Gürcülerle ilgili bilgilerinde de görüleceği üzere Timur'u, Tanrı'ya karşı işlenen günahların bir cezası olarak takdim eder. Bütün bunlar saldırılarının dindaşlarını da içine almasına karşın yazarın Timur'a karşı olumsuz bir bakış açısına sahip olmadığını göstermektedir.

$\mathrm{Bu}$ açılardan kıymeti haiz olmasına karşın eserin A. Kern'in 1938 y1lında bazı kısımlarını yayınlamasından bugüne kadar tam bir Latince edisyonu yapılmamıştır. Oysaki eserde daha pek çok ilgi çekici kısımlar vardır. Mesela Türkiye, Türkistan ve Hindistan ile ilgili bölümleri ${ }^{47}$ bugün için faydalanılacak durumda değildir ve çalış1lması için zor bir paleografyaya

\footnotetext{
${ }_{45}^{44}$ A. Luttrel, a.g.m, s.218.

${ }^{45}$ Nitekim Doğu'da misyonerlik faaliyeti içinde olan pek çok kimsenin de Batıdaki dinî meseleleri bu şekilde algıladığı Niemli Dietrich'in eserindeki ifadelerden de anlaşılmaktadır. Bk. A. Luttrel, a.g.m, s.218.

${ }^{46}$ Apokaliptik bilgi, dinî olmayan, ancak zaman içinde dinî bir kural veya anlayışa dönüşen bilgilere verilen addır.

${ }^{47}$ Eserin içindekiler tablosu L. Tardy tarafından çıkarılmıştır. Bk. L. Tardy, a.g.m, s.88, 89.
} 
sahip olan Latince nüshasının ${ }^{48}$ matbu hale getirilmesini beklemektedir. Bundan ötürü çalışmamızda A. Kern'in edisyonunu takip ettik. Bu kısım da daha önce tam olarak çevrilmemiştir. Sadece yukarıda da ifade ettiğimiz gibi L. Tardy, Kafkasya ile ilgili kısımları İngilizce'ye tercüme etmiştir. Çalışmamızda bu çeviriyi kendi tercümemizle de karşılaştırdık. Bununla birlikte L. Tardy, Latince el yazması üzerinde çalışabildiğinden Kern nüshasında aktarılmayan bazı kısımları da tercüme etmiştir. Mesela Tardy tercümesinde Kern nüshasinda yer almayan Abhazya, Migrelya ve Dağıstan kısımlarının tercümesi de yer alır. Yazar, Latince edisyonunu yayıma hazırlamadığı için bu bölümler incelememiz dışında kalmıştır. Bundan ötürü Kafkasya üzerine çalışan araştırmacılara L. Tardy'nin tercümesini de incelemelerini tavsiye ediyoruz. Bizim çalışmamız ise daha mütevazı bir amaç çerçevesinde, Kern nüshasında yer alan Türk tarihini alakadar eden bir takım kısımların tercümesi olarak takdim edilmektedir. İncelememizin konuyla ilgilenen araştırmacılara katkı sağlayacağını düşünüyoruz.

\section{Dünya Bilgisi Kitapçığı}

\section{Timur’a Yorulan Apokrif Metinler ve Haçlı Seferi İlanı Üzerine}

(...) (Piskopos Nerxsis ${ }^{49}$ ) Bunları yazdıktan sonra Timur $^{50}$ hakkında kehanette bulundu. Denilene göre zamanımızın 1000'li yıllarında, aslında ise tam olarak 1370 'de, doğudan okçu urka mensup, demir adında ${ }^{51}$ ve orta boylu, uzun saçlı ve onları kadınlar gibi düzenleyen ${ }^{52}$, sesi korkunç, atları kısa ve hızlı olan ${ }^{53}$ korkunç bir kişi ortaya çıkacak.

Anlatılanlardan fazlası o, doğudan batıya, ardından da kuzeye ve güneye yayıldı. Tüm kral ve prenslerle savaştı ve hiç kimse ona karşı koyamadı. Tanrıya taptı ve pek çok başağı yok etti ${ }^{54}$. Zamanında Hıristiyanlara saldırdı, kentlerini, topraklarını ve kiliselerini tarumar etti, çocuklarını ailelerinden ayırd1, zenginlerle güçlüleri kendisine ayırd1 ${ }^{55}$. Kenan topraklarına

48 Metnin el yazması nüshalarından birisine internet üzerinden erişmek mümkündür. http://www.manuscriptorium.com/apps/main/index.php?request=show tei digidoc\&docId=s et20100208 76_26\&client=direct\&dd_listpage_pag=1r erişim 15 Ağustos 2012.

${ }^{49} 364-373$ yillarında Piskoposluk yapan Ermeni bir din adamı.

${ }^{50}$ Metinde Timur adı Themurlan, Themurbey, Themurlank olarak birden farklı şekilde geçer.

${ }^{51}$ Nomen habens ferrum.

${ }^{52}$ Cesarios (Caesariatus/Caesarios) crines habens et mandans servare illos sicut mulieres. Cümlenin ikinci kısmında görüşlerinden faydalandığım Oulu Üniversitesinden Dr. R. Hautala'ya (Finlandiya) teşekkür ederim.

53 İfade Splitli Thomas'ın Moğol atına ilişkin bilgilerini akla getirir. Bk. J.R. Sweeney,

"Thomas of Spalato and the Mongols: A Thirteenth Century Dalmatian View of Mongol

Customs", Florilegium, 4/1982, s.168.

${ }^{54}$ Deum colet et vicia mutla delebit.

${ }^{55}$ Cummulabit/Cumulabit? 
geldiğinde elçileri saldırmadığı, ancak memnuniyetle barış içinde olduğu Frank olarak anılan ${ }^{56}$ batıdaki prenslere gönderdi. Gönderilenlerden birisi de Asman adında, ki Asman onların dilinde gökyüzü ${ }^{57}$ demektir, uhrevi ve çok dindar bir kimseydi. O, Hıristiyanların prensleriyle güzel din (=Hıristiyanlık) hakkında pek çok konuda müzakere etti ve ardından da maiyetindeki diğer kimselerle birlikte Katolik (Hıristiyanlık) inancına geçti ${ }^{58}$. Bu sırada batılı dindar Hıristiyan prensler çok güçlülerdi ve hem içerde hem de dişarıda Haçlı sancağına sahiplerdi. (...)

Herkes, çok sayıda kehanete sahip Müslümanlar gibi (Haçlı) sancağı altında toplanmalı. Kehanetler okunduğunda herkes bunlara, İsa'nın (yeryüzüne) ineceğine inandığımız gibi inanacak. Bunun ardından da Hıristiyanlar kendilerini sanki Frankların ilerleyişlerinde olduğu gibi koruyacak ve özgür olacaklar. Pek çok büyük prens, Tanrı'nın sadece İsa'nın resmi ile süslediğimiz Haç işaretini göğsümüze takmamızı istediğini ve özgürlüğe böyle sahip olacağımızı söylüyor. Fakat kimileri bu konuda şüpheliler ve harekete geçmiyorlar. Makul olan bazıları ise duyduğuma göre diyorlar ki: "Bunun olmaması imkânsızdır. Ancak Franklar arasında büyük günahlar ve ayrllıkların olmasından ötürü harekete geçilmemiştir. Bu nedenle Tanrı sınırına çekilmiştir ${ }^{59}$. (Oysaki) Türk Bayezid ${ }^{60}$, pek çok kez halkına demiştir ki: "Franklar iki papaya sahip oldukça" onlarla mücadele etmekten çekinmiyorum. Fakat onlar (=Papalar) bir olurlarsa onlarla barlş yapmak lazımdır". Bunu uyumu cesaretlendirmek ve ilahi isteğin ifşası adına yazıyorum.

\footnotetext{
${ }^{56}$ Doğuda Frank tabiri Johannes'in de ifade ettiği gibi Batılıların tamamı için kullanılmıştır. Kelime ve kullanımı ile ilgili olarak bk. B. Lewis, "Ifrandj mad”, Encyclopedia of Islam 2, Vol. III, Leiden 1986, ss.1044-1046.

${ }^{57}$ Metinde celum olarak geçiyorsa da caelum olarak değerlendirilmiştir.

58 Timur'un Johannes'ten önce Avrupa'ya gönderdiği elçilerden sadece İspanya'ya giden Hac1 Muhammed al Kazi bilinmektedir. Bk. L. Lockhard, a.g.m, s.375; A. Luttrel, a.g.m, s.211; İ.İ. Umnyakov, a.g.m., s.190. Doğu Roma İmparatorluğunun Bayezid'a saldırmas1 için temaslarda bulunmak üzere İstanbul'a Francis adlı bir dominiken rahibe eşlik ederek giden bir Müslümanın varlığı da kaynaklarda yer bulmuştur. Ancak ismi bilinmemektedir. Bk. P. Jackson, a.g.e., s.239.

${ }^{59}$ Ideo deus elongavit terminum hunc. Burada terminus kelimesinde yazar muhtemel bir söz oyunu yapmaya çalışıyor.

${ }^{60}$ Metinde Turc Baazica.

${ }^{61}$ Burada Fransa ile Papalık arasındaki anlaşmazlıklardan ötürü büyük şizma adı verilen iki Papalı dönem kastedilmektedir. Bu dönem ile ilgili olarak bk. H. İnalcık, Rönesans Avrupası, Türkiye İşbankası yay., İstanbul, 2012, ss.14-16.
} 


\section{Arnavutluk ${ }^{62}$}

Katolik Hiristiyanların hemen ötesinde Albanya (Arnavutluk) olarak anılan büyük bir ülke bulunur. En büyük kenti Hıristiyanların elinde bulunan Duracium'dur $^{63}$. Bu kent Adriyatik veya Ege denizi ${ }^{64}$ kıyısında bulunur. Bugün Türklerin kenti tarumar etmeleri ve pek çok insanı esir olarak götürüp insansızlaştırmalarından ötürü kötü durumdadır ve arda kalanlar da bitap düşmüş durumdadırlar. Hiç kimsenin erişemediği yüksek dağlarında kimse yaşamaz. Bu dağlarda enfes şahinler ve büyük vahşi hayvanlar bulunur. Kent ahalisi zengin ve kibar değildir ${ }^{65}$. Halkı vahşi ve kabadır. Kendilerine has bir dil ve alfabeye sahiptirler. İnsanları Greklerin inancına bağlıdırlar (=Ortodoksturlar), bununla birlikte Latinlere çok yakındırlar ve denizcilikte ileri gitmişlerdir. Katoliklere benzer din adamları vardır. Burada Dominiken ve Fransisken rahipler de bulunur. Bu ülkenin doğusunda Grekya, batısında Dalmaçya veya Adriyatik denizi, güneyinde İon veya Barbar denizi, kuzeyinde ise Sırbistan ${ }^{66}$ yer alır. Buranın (=Arnavutluk'un) hâkimi uzun bir zaman boyunca Türk Bayezid idi. Şimdi Timur tarafindan özgür kılınanlar (=Arnavutlar) eğer yapabilirse Kont Lazar' $1 n^{67}$ başa geçmesini dilemektedirler ${ }^{68}$.

\footnotetext{
${ }^{62} \mathrm{Bu}$ kısımdan önce Doğu Hıristiyanları ile ilgili bir başlık vardır. Yazarın buradaki ana amacının onların dini akidelerini bildirmekten çok kendi kilisesinin propagandasını yapmak olduğu anlaşılmaktadır.

${ }^{63}$ Doğu Roma kaynaklarında Dyrrachion olarak geçen Draç kenti. Kent ile ilgili olarak bk. T.E. Gregory, "Dyrrachion", The Oxford Dictionary of Byzantium, Vol.I, Oxford UP, 1991, s.668.

${ }^{64}$ Metinde Egei maris.

${ }^{65}$ Divicias et policias civiles non habent.

${ }^{66}$ Metinde Rascia.

${ }^{67}$ Yazarın Lazar adıyla bahsettiği kişi Lazar'ın oğlu Stefan'dır. Kaynaklarda ondan Stefan Lazereviç olarak bahsedilmesi muhtemelen yazarı Stefan'a böyle bir ad takındırmaya sevk etmiştir. Ankara muharebesinde Timur'un dikkatini çekecek kadar şiddetli bir şekilde çarpışan prens, ülkesine döndükten sonra bağımsız kalacağı ümidiyle bazı temaslar kurmuşsa da kısa zamanda Türk hâkimiyetinden çıktığı takdirde Doğu Roma veya Macar İmparatorluklarının hâkimiyetine girmek tehlikesiyle karşı karşıya kalmıştır. Dahası ülkesinde Rus kaynaklarına girebilecek derecede şiddetli bir taht kavgası da yaşamış, ancak sonrasında tahtını yeniden elde etmeyi başarmış ve iktidarının sonuna kadar Türklere bağlı bir hükümdar olarak idaresini sürdürmüştür. Ankara muharebesinden sonra Sırbistan'daki durum ile ilgili olarak bk. S.M. Cirkovic, The Serbs, translation by V. Tosic, Blackwell Publishing, 2004, s.87 vd.

68 Arnavutların böyle bir tasarısının olup olmadığını tespit edemedik, ancak onların Balkanlarda Osmanlı idaresine uzun yıllar direnmiş olmaları dikkate alınacak olunursa Ankara muharebesinden sonra Johannes' in ifade ettiği şekilde bir tutum takınmış olmaları mümkündür.
} 


\section{Sirbistan ve Bulgaristan}

Arnavutluk'un doğusunda Sirplar ${ }^{69}$ bulunur. Onlar Türklere vergi ödeyerek yaşarlar. Kendilerine özgü dilleri vardır, Grekleri takip ederler (=Ortodoksturlar), zamanında Türklerin idaresi ve Lazar'ın hükmü altındaydılar. Kuzeyde Vulgaria veya Bulgaria bulunur. Burası güzel bir ülkedir, fakat Türkler tarafindan tarumar edilmiştir. Kendilerine has bir dilleri vardır ve Latinler gibi konuşurlar ${ }^{70}$. Romalılar onlara gelmiş ve İmparator Romanus bu toprakları ve aynı zamanda Makedonya'yı eline geçirmiştir. Roma halkı burayı güzel bir ülke olarak gördü, kadınlarını aldılar ve buraya yerleştiler. İşte bundan ötürüdür ki Bulgar dilinde Bulgaristan Romana olarak anılır. (...)

\section{Valaçya ${ }^{71}$}

Buranın ötesinde (=Bulgaristan) Büyük veya Pont olarak anılan denizin ${ }^{72}$ civarında Valaçya ${ }^{73}$ bulunur. Büyük bir ülkedir ve kendi idarecisine sahiptir. Türk (=Bayezid) pek çok kimseyi hakimiyeti altına almış ve vergiye bağlamışsa da buranın efendisine henüz boyun eğdirememiştir. Valaçya, büyük ve küçük olarak anılır. Ülke içinden Almanya'dan Macaristan'a ve aynı zamanda Valaçya'ya doğru akan ve nihayetinde Cenovalıların hâkimiyetinde bulunan Nicostomus ${ }^{74}$ taraflarından Büyük Denize dökülen dünyanın büyük ırmaklarından Tuna geçer. (Irmak) kurt kemiği manasına gelen Nicostomus'tan, denildiğine göre, denize öyle bir dökülür ki burada çok sayıda adacık ve boğaz oluşur. Ülkede büyük kentler yoktur, ancak pek çok çiftlik yer alır ve çok sayıda canlı barındırır. Ülke çok bereketlidir. Şarap az üretilir, ancak suları gür ve ovaları çoktur. Ülke ahalisi din açısından

\footnotetext{
${ }^{69}$ Metinde Rassi.

${ }^{70}$ Burada herhalde yazar Latince kökenli bir dil olan Romence'den bahsetmektedir.

${ }^{71} \mathrm{Bu}$ başlık altındaki bilgiler Romence olarak kaleme alınmış şu çalışmada da incelenmiştir. Bk. Ş. Papacostea, "Un Calator in Tarile Romane la İnceputul Veacului al XV-lea", Studi Revista de İstorie, Tom.18/1, 1965, s.171-174.

${ }^{72}$ Karadeniz Büyük Deniz manasına gelecek şekilde Latin kaynaklarında Mare Maius, İtalyanca olarak ise Mare Maggiore olarak geçer. Mare Nigrum yani Karadeniz olarak ilk defa Doğu Roma ile Venedik arasındaki bir ticaret anlaşmasında (1338) kullanılmıștır. V.V. Bartold, "Islam na Çernom More", Soçineniye, Tom VI, Moskva, 1966. s.665. Karadenizin adındaki bu değişim, Akdeniz ve Kızıldeniz kullanımları da dikkate alındığında, Türk etkisi altında cereyan etmiş olsa gerektir. Metinde bundan sonra geçen Karadeniz kullanımı yazara değil, tarafimıza aittir.

${ }_{74}^{73}$ Metinde Volaquia.

74 Bugün Romanya'nın Tulcea bölgesindeki Licostomo'dan bahsedilmektedir. Kent bir Ceneviz kolonisi olarak XIII ve XIV. yüzyıl Karadeniz ticaretinde önemli yer tutmuștur. Kent ile ilgili olarak bk. M. Balard, La Romanie Genoise (XIIe debut XVe siecle), Vol. I, Genova, 1978, s.145, 146; H. İnalcık, Osmanlı İmparatorluğunun Ekonomik ve Sosyal Tarihi, C.I, çev. H. Berktay, Eren yay., İstanbul 2000, s.328.
} 
Greklere yakındır. Bununla birlikte bizim Dominiken ve Fransiskenlerin makamları da çok sayıdadır ve yine kalabalık sayıdaki Töton yerleşimci de burada yaşar. Kentin hâkimi, ilerleyen y1llarda Dominiken kardeşlerin birisinin sayesinde Katolik inancımıza döndü. Bu bölgenin doğusunda Karadeniz, güneyinde Constantinopolis, batısında Albanya, kuzeyinde ise Rusya ve Litvanya bulunur. Bu halkların hepsi Macar Kralı muhteşem kişi Ludwig'in 50 y1 idaresinde kalmıştır. Tatarya'ya ${ }^{75}$ kadar uzanan bu bölgeler, onun sözünden korkan Türkler buraya girinceye dek ona vergi ödemişlerdir. Ölümünden sonra ise ayrılıkların ortaya çıkmasından ötürü bahsedildiği üzere Valaçya hariç, tamamı Türk efendisinin hâkimiyetine girmiştir. Yukarıda ifade edilen Venedik'e kadarki bölgeler ile ilgili olarak Türk Bayezid, benim de bulunduğum sirada efendi Timur'a gönderdiği elçiler kanalıyla, eğer (Timur) barış konusunda söz verir ve topraklarına girmezse her sene 100.000 Hıristiyan esiri göndereceğine dair söz vermişti ${ }^{76}$. Ancak o, (Bayezid'ın topraklarına) girdi ve onu yok etti ki bilindiği üzere bunların ittifak halindeki Hıristiyanların meylinden ötürü yapıldığını bildirmiştir ${ }^{77}$.

\footnotetext{
${ }^{75}$ Metinde Tartarya.

${ }^{76}$ De supradictis provinciis usque Venecias Turcus Baazica promisit per nuncios me presente domino Themurlan mittere omni anno c. milia Christianorum captivorum si dimitteret (promitteret olmalı) eum in pace et non intraret patriam suam. Aralarındaki ilk yazışmanın şiddetine rağmen Yıldırım Bayezid'ın Timur'un Suriye seferinden sonra anlaşmaya meylettiği dikkati çekmektedir. Özellikle Timur'un III. mektubuna verilen cevapta Sivas'tan el çekmesini uygun bir üslup içinde rica eder. IV. mektuba verilen karşılıkta da Yıldırım'ın sert üslubu yerini karşı tarafi yatıştırıcı bir söyleve bırakır. Söz konusu mektuplar için bk. A. Daş, "Ankara Savaşı Öncesi Timur ile Yıldırım Bayezid'in Mektuplaşmaları”, Türkiyat Araştırmalart Dergisi, S.15/2004, s.164, 165, 166, 167. Ayrica bk. İ. Aka, a.g.e., s.27. Mektuplarda Johannes'i doğrulayan bir ifade bulunmamakla beraber Bayezid'ın üslubundaki değişim, mektuplara geçmeyen böylesi bir sözün ifade edilmiş olabileceğini düşündürmektedir.

${ }^{77}$ Dixit hoc fecisse amore Christianorum quia erant in liga secum. Daha önce Timur hem Batıdaki devletlere hem de Doğu Roma İmparatorluğuna elçiler göndermiştir. Batılı devletlerden, özellikle de Venedik'ten Boğazları kapatmasını, Doğu Roma İmparatorluğundan ise Bayezid ile herhangi bir barış anlaşması imzalamamalarını istemiştir. Bk. P. Jackson, a.g.e., s.239. Boğazların kapanmasını istemesi muhtemelen, A. Luttrel ve görüşlerini Clavio'ya dayandıran (Clavijo, a.g.e., s.73) P. Jackson'un düşündüğünün tersine (A. Luttrel, a.g.m, s.219; P. Jackson, a.g.e., s.239) Bayezid'ın ve ordusunun Altın Orda Hanı Toktamış gibi elinden kurtulmasını istememesiyle ilgili olsa gerektir. Doğu Roma'nın Bayezid ile barış imzalaması ise Bayezid'ın kuvvetlerinin en azından bir kısmını muharebe dışı bırakmak niyetiyle izah edilebilir. Bu temaslara karşın taraflar arasındaki ilişkileri bir müttefik ilişki olarak değerlendirmek mümkün değildir. Bundan ötürü söz konusu ifadeyi Johannes'in diplomatik temasları çerçevesinde değerlendirmek lazımdır.
} 


\section{Rusya}

Kuzeyde büyük bir ülke olan Rusya veya Ruthenya bulunur. Büyük ve küçük olarak iki parçadan oluşur. Pek çok hükümdar (=knez) bulunur. Fakat bunlar arasında küçükteki Rusya'nın İmparatorudur ${ }^{78}$ ve kendi dillerinde Susman olarak anılır ${ }^{79}$. İç ve dış Rusya vardır ${ }^{80}$. İç Rusya'da Moskova ${ }^{81}$ adı verilen büyük bir kent bulunur. Buradan tüccarlar kısa bir yolla Çin'e ${ }^{82}$ giderler $^{83}$. Rusya'nın bir diğer kısmı Büyük $\operatorname{Han}^{84}$ veya Tatarların ${ }^{85}$

${ }^{78}$ Sed minor inter ipsos est imperator Russie. Burada yazar esasen Rusya'daki Büyük Knezlik kurumunu ifade etmektedir. Zira Rusya'da İmparatora karşıllk gelen Tsar kelimesi resmi olarak ancak IV. İvan tarafindan 1547'de kullanılmaya başlanmıştır. Bk. İ. Kamalov, Altın Orda ve Rusya: Rusya Üzerindeki Türk-Tatar Etkisi, Ötüken yay., İstanbul, 2009, s.237.

79 Johannes burada, A. Kern'in de ifade ettiği üzere, Rusya Büyük Knezi I. Vasiliy ile Bulgar kralı Şişman'ı karıştırmıştır. Bk. A. Kern, a.g.m, s.104. V.A. Martınçyuk bunun nedeni ile ilgili ilgi çekici, ancak ayrıca araştırmaya gerek duyulan bir takım bilgiler verir. Ona göre bazı Latince eserlerde Rusya ile Bulgaristan tek bir ülke gibi değerlendirildiğinden böylesi bir hataya düşülmüştür. Bk. V.A. Martınçyuk, "Rus i Litva v Soçinenii Ionna de Galonifontibusa", Issledovaniya po Istorii Vostoçnoy Evropl, Vıp. IV, /2011, s.82. Ancak bu doğru olsa bile Johannes'in Bulgaristan ile ilgili ayrı bir başlık açması görüşünü şüpheli hale getirir.

${ }^{80}$ Rus kaynaklarında ülke Büyük-Küçük, İç-Dış olarak ayrılmamaktadır. Martınçyuk bu tabirlerin Doğu Roma literatürüne ait olduğunu ve Johannes'in bunun tesirinde kaldığını ifade etmiştir. Bk. A.V. Martınçyuk, a.g.m, s.82.

${ }^{81}$ Metinde Mosco.

${ }^{82}$ Metinde Cathay.

${ }^{83}$ Yazarın aslında Moskova'dan Saray yoluyla Sarayçuk'a ulaşan ve buradan da Ürgenç yoluyla Çin'e uzanan yoldan bahsettiği anlaşılmaktadır. Zira söz konusu dönemde Moskova'dan yola çıkmak isteyen bir kişi öncelikle İdil üzerinde yer alan Saray'a gitmek mecburiyetindeydi. Nitekim XIV. yüzyılın ilk yarısında önemli bir ticaret kitabı kaleme alan Pegolotti, Moskova'dan Çin'e uzanan herhangi bir yolun bulunduğundan bahsetmez. Buna karşın, Saray ve Sarayçuk'tan Ürgenç'e uzanan yol ile ilgili önemli bilgiler verir. Bk. Francesco Balducci Pegolotti, La Pratica Della Mercatura, ed. A. Evans, Cambridge, 1936, s.21, 22. Ayrica bk. A.Yu. Yakobovskiy, a.g.e., s.94. Yine aynı y1llarda buralarda bulunan bir Fransisken rahibinin notlarında da Kefe'den önce Saray kentine ve ardından da Sarayçuk'a gelindikten sonra Ürgenç'e doğru gidildiği görülmektedir. Bk. S.P. Karpov, “Ot Tanı v Urgenç: Eti Trudnıye Dorogi Srednevenov'ya”, Sredniye Veka, Vıp. LXI/2000, s.221, 222. Sultaniyeli Johannes'in yanlış olmamasına rağmen eksik olan kaydı daha önce A.V. Mantınçyuk'un işaret ettiği üzere, Moskova ile ilgili Batı literatüründeki ilk bilgiyi teşkil etmesi açısından önemlidir. Bk. A.V. Mantınçyuk, a.g.m, s.82. Bununla birlikte yazar, Moskova ile ilgili bilgilerinin Doğu Roma menşeli olduğunu dile getirir. Ancak buna katılmak mümkün görünmemektedir.

${ }^{84}$ Metinde Cay.

${ }^{85}$ Metinde Tartar. Tatar kelimesinin Latin kaynaklarında bu şekilde ortaya çıkması esasen kelimenin Hiristiyan teolojisinde cehennem manasına kelen Tartar kelimesiyle benzeşmesiyle ilgilidir. Moğol istilasından sonra yazarlar muhtemelen kasti bir şekilde kendilerine saldıran düşmanlarına bu şekilde bir ad vermekten kendilerini alamamışlardır ki bundan sonraki dönemlerde de bu kullanım devam etmiştir. Kelimenin ortaya çıkışı ve gelişimine ilişskin olarak bk. P. Jackson, a.g.e., s.59. 
İmparatoruna vergi ${ }^{86}$ ve silahlı kuvvetlerini vermek ${ }^{87}$ geleneğine sahiptir. Şimdilerde, bir zaman pagan olan, ancak şimdi tamamı olmasa da genellikle dindar Hıristiyanların yaşadığı Polonya'nın kralı Vivold'un hâkimiyeti altındaki toprakların tamamında Dominiken tarikat arhiepiskoposlukları, piskoposlukları ve diğer dinî ve teftiş kurumlarını kurmuşlardır ki "Rusya ve Valaçya müfettişliği” adı ile anılırlar. Rusya (ayrıca) çok soğuk bir ülkedir.

Kendilerine özgü bir dilleri ve Hıristiyanlardan aldıkları bir alfabeye sahiplerdir ${ }^{88}$. Hiçbirisi Grek (inancını) takip etmez ${ }^{89}$, fakat Constantinopolis'teki patriklik kutsallığını elinde tutar. Yani onlara isteklerine uygun olarak bir arhiepiskopos atanı ${ }^{90}$. Doğu sınırlarında Tatarya, güneyinde Valaçya ve Grekya, batısında Polonya ve kuzeyinde ise Dağın ötesi ve Buz denizi vardır. Daha da kuzeyinde ise dünyanın sınırından başka bir yer yoktur.

Dominiken ve Fransisken kardeşler bu ülkede epey çok makama ve müfettişliğe sahiptirler. Batısındaki Litvanya küçük bir ülkedir. (Sakinleri) Bir zamanlar pagandılar, ancak şimdi tamamı değilse de İsa'nın lütfu ile Hiristiyandırlar.

\footnotetext{
${ }^{86}$ Altın Orda Hanlığı'nın Rusya'dan vergi toplaması meselesi esasen kendi içinde ikiye ayrılır. İlk dönemde Moğol vergi görevlileri bizzat Rusya'nın çeşitli yerleşim birimlerine gelerek insanları saymış ve vergi toplamışlardır. Bu 1257 ile 1260 yılı arasında devam eden faaliyetlerde kendini iyiden iyiye gösterir. Bk. A.T. Özcan, Moğol-Rus İlişkileri 1223-1341, Ege Üniversitesi Sosyal Bilimler Enstitüsü Basılmamış Doktora Tezi, İzmir, 2010, ss.153164. Ancak 1276 'dan sonra bu usul büyük oranda terk edilerek Büyük Knezler görevlendirildiler. Bununla birlikte çeşitli örnekler bu sistemin Moğol maliyesi tarafindan denetlendiğine işaret eder. Nitekim Büyük Knez Vasiliy Aleksandroviç vergi konularında azarlandığı gibi Tver knezi Mihail'in idam edilmesiyle neticelenen yargılaması sırasında en çok bu mevzu gündeme getirilmiştir. Bk. A.T. Özcan, a.g.t, s.191, 192, 264.

${ }^{87}$ Rus birliklerinin Altın Orda Hanlığının seferlerine iştirak etmelerine dair bk. A.T. Özcan, a.g.t, ss.169-173, 202-213; Z.V. Togan, "Voyennaya Kampaniya Timura 1395 goda na Ukraine i Severnom Kavkaze", Zolotordinskaya Tsivilizatsiya, Vip.II/2009, s.225, 226; G. Vernadsky, Moğollar ve Ruslar, çev. E.B. Özbilen, Selenge yay., İstanbul, 2007, s.321; Yu. Poçekaev, "Russkiye Voyska v Zolotoordınskih Voennıh Kampaniyah", Zolotoordınskaya Tsivilizatsiya, Vip III/2010, ss.36-44.

${ }^{88}$ Yazarın bahsettiği alfabe Doğu Roma kilise teşkilatı içerisinde yetişen Slav asıllı bir din adamı olan Kiril'in oluşturduğu alfabedir.

${ }^{89}$ Yazarın verdiği bilgi yanlıştır. Zira Ruslar'ın Ortodoksluğa bağlılıkları Floransa-Ferrara konsilinde Ortodoksluğun Katoliklik içerisine alınmasına karşı çıkılmasında olduğu gibi pek çok tarihi mevzuda karşımıza çıkar.

${ }_{90}$ Rusya Patrikliği resmen kurulana kadar Kiev metropolitlerinin tamamı İstanbul Patrikliği tarafindan tayin edilen kimselerden olmuştur. Hatta 1204 sonrasinda da bu gelenek devam ettirilmiştir. G. Vernadsky, a.g.e., s.184. İstanbul Patrikliği ile Rusya metropolitliği arasındaki söz konusu bağlantı için bk. J. Mayendorf, "From Byzantium to Russia: Religious and Cultural Legacy", Rome Constantinople Moscow, St. Vladimir's Seminary Press, 2003, s.113-130.
} 


\section{Gotlar, Tatarlar ve Kırım}

Büyük denizin yakınında Tat ${ }^{91}$ ve az sayıdaki Got ${ }^{92}$ adlı iki küçük halk vardır. Din olarak Grekleri takip ettikleri gibi Grek alfabesini kullanırlar. Gotlar İskoçların soyundan gelir ${ }^{93}$ ve İngilizler gibi konuşurlar ${ }^{94}$. Tatarya veya Kumanya' daki ${ }^{95}$ Kefe'nin yakınlarına yerleşmişlerdir. Batıda Valaçya ve kuzeyde Rusya'dan başlayıp Çin' ${ }^{96}$ kadar geniş bir alana uzanan ülke Tatarya veya Kumanya'dır ve ülkenin doğu kısmı Harezm ve bir çöle ${ }^{97}$ kadar yayılmış durumdadır. Kuzeyinde Rusya veya Yhabri ${ }^{98}$ ve bozkır bulunur. Batısında Karadeniz veya Azak bulunur. Güneyinde engin Kafkas dağlarr ${ }^{99}$ ve Bakü civarındaki deniz ${ }^{100}$ veya Hazar veya İran denizi yer alır ${ }^{101}$.

91 Tatlar Kafkaslarda yaşayan İranî bir halktır. Tatlarla ilgili olarak bk. L. Tardy, a.g.m, s.101/28.dp.

${ }^{92}$ Gotlar Sibirya'dan Almanya'ya kadar uzanan çok geniş bir alana yayılmıș Cermen boylarından biridir. Onlar, Hunlar Karadeniz'in kuzeyinde geldiklerinde Don irmağının her iki yakasına yayılmış önemli bir gücü temsil ediyorlardı. Ancak Hunlarla giriștikleri mücadelelerde yenilerek Attila'nın ölümüne kadarki sürede Hunlara bağlandılar. 463'teki Ogur göçü sırasında elde ettikleri bu konumu yitirdiler. Bundan sonra artık Don ırmağı çevresindeki nüfus üstünlüklerini Türk halklarına terk ettikleri, bir kısmının batıya doğru çekilmesine karşın diğer bir kısmının ise Kırım sahillerinde tutunmayı başardıkları görülmektedir. Nitekim VI. yüzyıla gelindiğinde Mangup'taki güçlü kale Got hâkimiyetinde bulunuyordu. $\mathrm{Bu}$, durum Hazar Kağanlığı'nın yıkıldığı dönemde de devam ediyordu. Bk. A. Madgearu, "The Place of Crimea and of the Kerch Strait in the Strategy of the Middle Byzantine Empire", Il Mar Nero, V/2006, s.193, 195, 200, 201. Kırım, Moğol hâkimiyetine geçtiğinde Gotlar Kırım'daki varlıklarını devam ettiriyorlardı. Nitekim Fransız kralının elçisi Rubruklu Willem, Kerson'un batısında Kırkyer'de, yani Çufut'ta Cermen dillerini devam ettiren Gotlarla karşılaşmıştır. Bk. Ruysbroeckli Willem, Mengü Han'ın Sarayına Yolculuk, ed.P. Jackson, D. Morgan, çev. Z. Kılıç, Kitap yay., İstanbul, 2010, s.84. Onlar varlıklarını Osmanlıların Kırım'1 ele geçirmelerinden sonra da devam ettirdiler. Daha önce A.A. Vasiliyev'in çok önemli bir çalışması olmakla birlikte (The Goths in Crimea, Cambridge, 1936) şu çalışma son yıllarda yapılan arkeolojik kazı neticelerini de barındırır. Bk. H. Bayner, Istoriya Krımskih Gotov, Ekaterinburg, 2001. Kırım'daki Got varlığı ile ilgili ayrıca bk. L. Tardy, a.g.m, s.101/29.dp.

${ }^{93}$ İskoçlar kök itibariyle Kelt asıllıdırlar.

94 Johannes'in İngiltere'de uzunca bir süre kalmış olmasına karşın Gotların İngilizlere benzer konuştuklarından bahsederek hataya düşmesi düşündürücüdür. Oysaki Johannes’ten 150 yıl önce Kırım'daki Gotlardan bahseden Rubruklu Willem dahi onların Almanca konuştuklarının farkına varmıştı. Bk. Ruysbroeckli Willem, a.g.e., s.84. Bunun zaman ile ilgili bir yanlış olmadığı anlaşılmaktadır. Zira Johannes’ten sonra Kırım'da bulunmuş Venedikli Jopashat Barbaro da Gotların Almanca konuştuklarını ifade eder. Bk. Josaphat Barbaro, Anadolu'ya ve Iran'a Seyahat, çev. T. Gündüz, Yeditepe yay., İstanbul, 2009, s.32.

${ }^{95}$ Metinde Comania.

${ }^{96}$ Metinde Cathay.

${ }^{97}$ Yazar burada Kızılkum çölünden bahsetmektedir.

${ }^{98}$ Yhabri kelimesi ile ilgili tartışmalar için bk. L. Tardy, a.g.m, s.102/37dp. Yazarın bu kelime ile Sibirya halklarını ifade ettiği anlaşılmaktadır.

${ }^{99}$ Metinde Coquas ve Caspeos olarak iki dağ olarak ifade edilmiştir. 
Bu krallıkta pek çok halk ve bölge bulunur ki bunlar Kumanya, Hazarya ${ }^{102}$, Yhabri, Ihugur ${ }^{103}$, Kepchacii ${ }^{104}$, Gumat ${ }^{105}$, Ivlach ${ }^{106}$, Kumuch ${ }^{107}$, Avar ve kuzeydeki ülkelerdeki bilinmez kalabalık tüm kavimler onların komşularıdır. Bunların dilleri tektir, fakat gramerleri ${ }^{108}$ tıpk1 İtalyanca ile İspanyolca arasındaki gibi birbirinden farklıdır. Krallık kapladığı alana göre dünyanın en kalabalık halklarının bulunduğu yer gibidir. Ülkenin ovaları geniştir, buna mukabil havanın soğukluğundan ötürü yerleşim azdır. Bazı yerlerde soğuktan hayvanların ve insanların hayatta kalmaları mümkün değildir. Bazı yerleri ise o kadar sıcaktır ki at sineği ve küçük sineklerden başkasının yaşaması mümkün değildir ${ }^{109}$. Çiftliklerin yakınında yetişenler hariç ağaç bulunmaz. Üzüm de üretilmez. Kentleri küçük ve birbirinden bağımsızdır. Halk çadırlarında yaşar ve hayvan dışkılarını yakarlar ${ }^{110}$. En önemli kentleri Saray'dır ${ }^{111}$. Hazarya'da ${ }^{112}$ Sultach veya Curim kenti vardır. Bir zamanlar

${ }^{100}$ Metinde Mare Bacu.

${ }^{101}$ Sınırların büyük oranda diğer kaynaklarla da uyumlu olduğu görülüyor. Deşt-i Kıpçak olarak ifade edilen bölgenin sınırları için bk. M. Kafalı, "Deşt-i Kıpçak ve Cuci Ulusu", Tarih Dergisi, S.25/1971, s.180, 181.

${ }^{102}$ Eski Hazar ülkesinin topraklarını ifade eden bu kelime Doğu Roma kaynakları yoluyla Latin yazınına geçmiştir. Hazarya kelimesi Altın Orda Hanlığı zamanında Latin devletlerle ticari ilişkiler zamanında yeniden ortaya çıkmıştır. Bk. M. Balard, "The Greeks of Crimea under Genoese Rule in the XIVth and XVth Centuries", Dumbarton Oaks Papers, Vol.49/1995, s.25; G.M. O'Riordan- M. Berindei, "Venise et la Horde d'Or fin XIIIe- debut XIV siecle", Cahiers du Monde Russe et Sovietique, Vol.29, Nu.2/1988, s.244.

${ }^{103}$ Burada Uygurlar ifade edilmektedir.

${ }^{104}$ Kelime açık bir şekilde Kıpçakları ifade etmektedir. Rubruklu Willem de onlardan Capchac (okunuşu: Kapçak) olarak bahseder. Bk. Ruysbroecli Willem, a.g.e., s.85.

${ }^{105}$ Bu halk Gizli Tarih’te de karşımıza çıkan Tumat kabilesidir. Bk. Moğolların Gizli Tarihi, çev. A. Temir, TTK yay., Ankara, 1995, s.160, 161; Moğolların Gizli Tarihçesi, çev. M.L. Kaya, Kabalc1 yay., İstanbul, 2011, s.205, 206. Plano Carpinili Johannes'in Tomiti ad1 altında değindiği halk da muhtemelen onlardır. Bk. C. Dowson, The Mongol Mission, New York, 1955, s.41. Ayrica bk. L. Tardy, a.g.m, s.102/46dp.

${ }^{106}$ Schiltberger ve Roger Bacon'un ifadeleri bu kelimenin Başkırt adı yerine kullanıldığına işaret etmektedir. Bk. L. Tardy, a.g.m, s.102/47dp. Ancak herhalde burada Başkırtların tamamından ziyade boylarından birisi ifade edilmektedir.

${ }^{107}$ Burada Dağıstan'da yaşayan Türkleşmiş Kumuklardan bahsedilmektedir. Bk. U. Tavkul, “Kumuk Türkleri”, Kırım Dergisi, C.13/50, 2005, s.29.

108 Yazar burada alfabeyi ifade eden literam kelimesini kullanmışsa da bir sonraki ifadesi, anlatmak istediğinin gramer ile ilgili olduğunu gösterir.

${ }^{109}$ Deşt-i Kıpçak ikliminin zorluğu Ibn Battuta tarafindan da gözlemlenmiştir. Bk. Ibn Battuta Seyahatnamesi, çev. A.S. Aykut, Yapı Kredi yay., İstanbul, 2010, s.515, 517.

110 Deşt-i Kıpçak'ta tezek kullanımından Ibn Battuta ve XVI. yüzyılda bölgede bulunmuş olan Tranowski de bahseder. Bk. Ibn Battuta, s.463; A.N. Kurat, Türkiye ve İdil Boyu, TTK yay., Ankara 2011, s.E.35.

${ }^{111}$ Burada Berke zamanında kurulan ve bundan ötürü de Saray Berke veya Yeni Saray olarak anılan kent ifade edilmektedir. Kent Özbek Han zamanında Deşt-i Kıpçak'ın en müreffeh kentlerinden birisi haline gelmiştir. Bir süre kentte bulunan Ibn Battuta kentin kalabalık ve 
büyük bir kentti, ancak şimdilerde yıkıntı halindedir ${ }^{113}$. Buradan 100 mil ötede meşhur ve kalabalık Kefe ${ }^{114}$ kenti bulunur ve dünyanın dört bir tarafından gelen tüccarlar burada bulușurlar. Doğunun dillerinin tamamıyla burada karşılaşılabilir. Bizzat ben burada 35 dil saydım. Denizin ötesindeki bu kent Hıristiyanların gözdesi ve büyük emtia kaynağıdır. Buraya Cenovalılar hâkimdir ve burada iyi kalitede ustalar ipek, chamalotto $^{115}$ ve diğer zanaatlar üzerine çalışır ${ }^{116}$. Azak kenti ${ }^{117} \operatorname{Don}^{118}$ irmağının ve Avrupa

büyüklüğünden bahseder. Bk. Ibn Battuta, s.517, 518. Kent ile ilgili olarak ayrıca bk. A.Yu. Yakubovskiy, Altın Ordu ve Çöküşü, çev. H. Eren, TTK yay., Ankara, 2000, ss.84-92.

${ }_{112}$ Metinde Gazaria.

${ }^{113}$ Metinde Sultach sive Curim olarak geçmektedir. Johannes'in Latince metnini yayınlayan A. Kern ve L. Tardy bu kenti Eski Kırım olarak ifade etmektedirler. Bk. A. Kern, a.g.m, s.107; L. Tardy, a.g.m, s.103/51dp. Kaynaklarda söz konusu kent sadece Kırım adıyla geçtiğinden (Ibn Battuta, s.464; A.Yu. Yakubovskiy, a.g.e., s.65) bu iddia mahiyetsiz olarak görülemeyecekse de, yazarın asıl ifade etmeye çalıştığı kentin Suğdak kenti olduğunu kabul etmek daha makul gözükmektedir. Nitekim Ibn Battuta da Suğdak ile ilgili bilgi verirken buranın Rumlarla Türkler arasındaki bir meseleden ötürü mahvolduğunu ifade etmiștir. Bk. Ibn Battuta, s.498. Aslında kent Özbek Han zamanında 1322'de Kara Bulat tarafından işgal edilmişti. Benzer bir hadise de 1327'de yani Ibn Battuta'nın buraya gelmesinden altı yıl önce Tolaktemir tarafindan tekrarlanmış ve bu sırada epey zarar görmüştü. Bk. W. Bartold, "Suğdak", MEB İslam Ansiklopedisi, C.XI, İstanbul, 1979, s.6. Solgat yani Eski Kırım ise zamanında Kırım'daki Altın Orda valisinin yerleşmiş olduğu bir nevi idari merkez konumundaydı ve Özbek Han zamanında müreffeh bir kent olduğu günümüze kadar erişen görkemli camisinden anlaşılmaktadır. Bk. N. di Cosmo, "Mongols and Merchants on the Black Sea Frontier in the Thirteenth and Fourteenth Centuries: Convergences and Conflicts", Mongols, Turks and Others, Eurasian Nomads and the Sedentary World, ed.R. Amitai and M. Biran, Leiden-Boston, 2005, s.396; A.Yu. Yakubovskiy, a.g.e., s.51. Suğdak'tan harap bir yer olarak bahseden Ibn Battuta'nın Solgat'ın ihtişamına değinmesi de Johannes'in bahsettiği kentin Suğdak olduğu fikrini güçlendirir. Bk. Ibn Battuta, s.464.

${ }^{114}$ Metinde Capha.

${ }^{115}$ Camlet devetüyünden, ancak bulunamadığında keçi kılından, ipek karışımlı bir çeşit kıymetli kumaştı. Camlet ile ilgili olarak bk. D. Jacoby, "Camlet Manufacture, Trade in Cyprus and the Economy of Famagusta from the Thirteenth to the late Fifteenth Century", Medieval and Renaissance Famagusta, ed. M.J. K. Walsh, Ashgate Publishing, 2012, s.1-42. Bu bilgiyi benimle paylaşan D. Jacoby'e teşekkür ederim.

${ }^{116}$ Ibn Battuta'nın verdiği bilgilere göre Kefe, azametli ve zengin bir görünüme sahipti. Bk. Ibn Battuta, s.463, 464. Cenovalılar, Altın Orda Hanı Mengü Timur zamanında 1266'da aldıkları yarlıkla, bu sırada küçük bir liman hüviyetine sahip olan Kefe'yi kontrolleri altına almışlardı. Bulunduğu konum ve limanının özelliklerinden ötürü Kefe kısa zaman içerisinde Kırım'ın en önemli liman ve ticaret merkezlerinden birisi haline geldi. Bk. H. İnalcık, a.g.e., s.328, 331; E.S. Zevakin, N.A. Pençko, "Oçerki po İstorii Genuezskih Koloniy na Zapadnom Kavkaze v XIII i XV vv.”, İstoriçeskiy Zapiskiy, T.3/1938, s.75 vd; M. Balard, a.g.e., s.114, 115; Y. Öztürk, Osmanlı Hâkimiyetinde Kefe 1475-1600, Kültür Bakanlığı yay., Ankara, 2000, ss.14-17; C. Orhunlu, "Kefe", Encyclopedia of Islam, V.4, Leiden, 1997, s.868.

${ }^{117}$ Metinde Tana.

${ }^{118}$ Metinde Thanay. 
ile Asya'yı birbirinden ayıran Sicie kentinin ${ }^{119}$ limanıdır $^{120}$. Burası ile ilgili pek çok şaşırtıcı şey söylenmiştir, fakat bunları geçiyorum. Şimdilerde savaştan ötürü oturmaya müsait değildir ${ }^{121}$. Boyun eğdikleri efendileri her gün ailelerinden evlatlarr ${ }^{122}$ zorla almak için gelir. Ancak neticede Timur kenti yok etti ve buradan neredeyse sayılamayacak kadar çok esir sürdü. Altın ve gümüşü olmayan efendiler bu kalabalıktan ayrıldı, buna malik olamayanlar ise hayvanlarını oğullarını ve kadınlarını onlara verdiler ve bunlar da hemen onları tüccarlara sattılar. İște vatan böylelikle bomboş edildi $^{123}$.

İdil olarak anılan buradan akar ve Hazar denizine dökülür ${ }^{124}$. Dendiğine göre kırk parçaya ayrılan kısımlarından birisi Azak Denizi'ne ve sonrasında

${ }^{119}$ L. Tardy kentin aslında Çerkez ülkesini ifade ettiğini ileri sürmüştür. Bk. L. Tardy, a.g.m, s.103/54dp. Johannes aşağıda Çerkez ülkesinden bahsederken Ziquia veya Tharquesia tabirlerini kullanıyorsa da Çerkezlerin Don taraflarına kadar yayılmış olmaları (M. Bala, “Çerkezler”, MEB İslam Ansiklopedisi, C.III, İstanbul, 1981, s.375, 376) ve isim benzerliği, L. Tardy'nin görüşünü doğrulamaktadır.

${ }^{120}$ Azak, Altın Orda zamanında Kefe gibi önemli bir liman kentiydi. Kefe'nin Cenovalıların elinde bulunmasına karşılık Azak 1333'te Venediklilerin eline geçti. Bk. H. İnalcık, "Azak", Encyclopedia of Islam, Vol.1, Leiden, 1986, s.808. Bu, Özbek Han tarafindan bir yarlıkla onaylandı ki bu metin günümüze erişmiştir. Bk. Y. Öztürk, a.g.e., s.272, 273; A.T. Özcan, "XV ve XVI. Yüzyıllarda Karadeniz'in Kuzeyinde Doğu Mallarına Dair", Belleten, C.LXXV/S.274, s.732.

${ }^{121} \mathrm{Bu}$ dönemde Azak gerçekten de oturulmaya pek müsait durumda değildi. Bk. M. Balard, a.g.e., s.155, 156.

${ }_{122}$ Yazar Parentes filios olarak ifade etmişse de ifade herhalde parentibus filios olmalıdı.

${ }^{123}$ Timur'un Azak kuşatması ile ilgili olarak bk. İ. Aka, a.g.e., s.21; Z.V. Togan, a.g.m, s.225; M.C. Baysun, "Azak", MEB İslam Ansiklopedisi, C.II, İstanbul, 1979, s.86, 87. Azak'ın yakılıp yıkılmasına paralel olarak Kırım'dan Sarayçuk'a ve Astrahan üzerinden Ürgenç’e uzanan ve buradan da Çin'e giden yol müthiș bir tahribata uğramıștır. Bk. İ. Aka, a.g.e., s.15, 21. Azak 1399 'da yeniden inşa edilmeye başlanmış ve kentin ticari durumunda iyileşmeler olmuşsa da (M. Balard, a.g.e., s.156; İ. Aka, a.g.e., s.132, 133) eski önemini kaybetmişti. Bk. C. Baysun, a.g.m, s.87; S.P. Karpov, "Dokumentı po Istorii Venetsianskoj Faktorı Tana vo Vtoroy Polovine XIV v.", Priçernomor'ye v Sredniye Veka, Vıı.I/1991, s.191. Bölgenin ticari etkinliğinin azalması XV. yüzyılda Deşt-i Kıpçak'ta bulunan Barbaro tarafından da müşahede edilmişti. Nitekim yazar eskiden ipek ve baharatın Astarhan üzerinden Azak'a giderken bu malların yaşadığı dönemde Suriye limanlarına aktığını dile getirir. Bk. Josaphot Barbaro, a.g.e., s.32. Timur'un bu saldırılarla Altın Orda Hanlığı'nın ekonomik hayatına darbe indirmeyi amaçladığı anlaşılıyorsa da (P. Jackson, a.g.e., s.240, 251/34dp.) bunun, daha önce G. Vernadsky tarafindan ifade edildiği gibi (G. Vernadsky, a.g.e., s.331.) Timur'un Altın Orda'nın kudretli zamanlarında büyük oranda Deşt-i Kıpçak'a kayan eski ipek yolunu önceki gibi yeniden İran üzerine sevk etmek politikasının bir parçası olduğunu kabul etmek daha yerindedir. Bu görüş muhtemelen Vernadsky'den bağımsız olarak, $H$. İnalcık tarafindan da dile getirilmiştir. Bk. H. İnalckk, a.g.e., s.274.

${ }^{124}$ Metinde Hedyl olarak geçen ırmak Türkçe eserlerde ilk olarak Kaşgarlı'nın divanında karşımıza çıkmasına karşın geçmişi çok daha gerilere gitmektedir. Nitekim Attila isminin bu 1rmaktan geldiği yönündeki ciddi iddialar bunu desteklemektedir. Bk. İ. Kafesoğlu, Türk 
da Büyük Deniz'e ulaşan Don ${ }^{125}$ irmağıdır. (İdil) Her yıl aylarca buz tuttuğundan insanlar ve hatta atlar, at arabaları ve develer üstünden karşı kıyıya geçer ${ }^{126}$. Tatarlar din açısından birbirlerinden farklıdır. Sarasinlerin sınırlarındaki halkın ve yerleșim birimlerinin büyük bir kısmı Sarasinlerin dinlerini takip eder. Orta ve en kuzeydeki topraklardakiler vahşi ve puta tapardır ${ }^{127}$. (Arda kalanların) Çoğu Hıristiyan'dır ve (diğerleri de) eğer onlara büyük bir zevk içinde dünyayı tek bir Tanrının yarattığını ve Muhammed'in de onun elçisi olduğunu anlatan Sarasinler engel olmazlarsa kolayca din değiştirebilirler ${ }^{128}$. Buna karşın bizim dinimiz daha zor olmasından ötürü pek azı bize gelir. Eğer nihayetinde dinlerini Katolikliğe

Milli Kültürü, Ötüken yay., İstanbul, 1998, s.71. Kelime ilerleyen yıllarda Hazar Kağanlığı vasıtasıyla Arap coğrafyacılarının eserlerine de girmiştir. Bk. R. Şeşen, İslam Coğrafyacılarına Göre Türkler ve Türk Ülkeleri, TTK yay., Ankara 2001, s.45, 50, 51 vd. Latin kaynaklarında ise ilk defa Rubruklu Willem'in seyahatnamesinde 1rmaktan Etilia adı ile bahsedilir. Bk. Ruysbroeckli Willem, a.g.e., s.124, 125, 149. Bu kullanım daha sonra Willem'in eserinden yararlanan Roger Bacon tarafindan da takip edilmiştir. Bk. The Opus Maius of Roger Bacon, Ed. J.H. Bridges, Volume I, London, 1900, s.361. Rubruklu Willem'in bu kelimeyi nasıl öğrendiği kesin olarak anlaşılamamaktadır. Latince kaynaklarda yer alan Hazarlara ilişkin bilgilerin, Doğu Roma kaynaklarından yapılan tercümelerle oluşturulduğundan ötürü, kelimenin Latince'ye Grekçe'den geçtiği ve Rubruklu Willem'in kelimeyi bu sayede öğrendiği düşünülebilir. Nitekim Simocatta'nın eserinde İtil ırmağı Til halinde -e harfini kaybetmiş bir halde kullanılmıştır. (Latincesinde: Haec in oriente ad fluvium Til accolit, quem Turcae Nigrum appellare solent) Bk. Corpus Scriptorum Historiae Byzantinae, editio emendatior et copiosior B.G. Niebuhri, Theophylactus Simocatta et Genesius, Bonnae, 1834, s.284. Buna karşın Willem'in eserine Türkçe kelimelerin varlığı (L.V. Clark, "The Turkic and Mongol Words in William of Rubruk's Journey (1253-1255)", Journal of the American Oriental Society, Vol.93/N.2, 1973, ss.181-189.) Etil kelimesini Kıpçak veya Bulgarlardan duyduğu hususunda kuvvetli bir delil teşkil eder.

${ }^{125}$ Metinde Thanay.

${ }^{126}$ İtil'in buz tuttuğundan Ibn Battuta da bahseder. Bk. Ibn Battuta, s.517.

${ }^{127}$ Türk ve Moğollarda söz konusu dönemde puta tapmak gibi bir adet bulunmadığı gibi pek çok kaynak yazarı onların tek Tanrı'ya inandıklarını kaydetmiştir. Bunlardan birisi olan Plano Carpinili Johannes, Moğolların görülebilir ve görünemez her şeyi yaratan tek bir Tanrı'ya inandıklarını dile getirir. Ancak inandıkları dinin çeşitli dini öneme sahip eşyaları kullanmalarına engel olmadığını belirtir. Bk. C. Dowson, a.g.e., s.9. Bu konuda ayrıca bk. J.P. Roux, Türklerin ve Moğolların Eski Dini, çev. A. Kazancıgil, Kabalcı yay., İstanbul, 2002, s.244.

${ }_{28}$ Burada Müslüman din adamlarının bozkırdaki dinî faaliyetlerinden bahsedilmektedir. Onların Deşt-i Kıpçak'ta İdil Bulgar Hanı'nın İslamiyeti kabul etmesinden itibaren varlık göstermelerine karşın Özbek Han zamanına kadar etkin olduklarından bahsetmek mümkün değildir. İslamiyetin bu dönemde Deşt-i Kıpçak’taki konumu, en iyi şekilde Ibn Battuta tarafindan gözlemlenmiştir. Bk. Ibn Battuta, s.464, 468, 469, 471, 474vd. Altın Orda Hanlığı'nın İslamlaşması ile ilgili olarak bk. D. DeWeese, Islamization and Native Religion in the Golden Horde, Pennsylvania State UP, 1994; A. Yu. Yakubovskiy, a.g.e., s.44, 100, 101; G.M. Davletşin, "Musul'manskoye Bogosloviye v Zolotoy Orde", Zolotoordınskaya Tsivilizatsiya, Vip. II/2009, ss.27-38. 
değiştirirlerse de ancak bir kısmı puta tapmayı bırakacaktır. Zira bunların onlara bereket verdiğine ve hayvanlarını vahşi hayvanlardan koruduklarına inanırlar ${ }^{129}$. Uzun uzadıya anlatmayı gerektirecek pek çok törenleri vardır. Hayvanları kurban etmede yaptıkları gibi pek çok din dışı işler yaparlar. Pek çok kadın ve evlada sahip olduklarında bazılarını hayvanlarıymışçasına satarlar, bunun sebebi olarak da çok sayıda kişiyi besleyemediklerini söylerler ${ }^{130}$. Bu ülkede Latin veya Katolik pek çok Hıristiyan vardır. Grekler, pek çok Ermeni, Ziqui, Got, Tat, Valaç, Rus, Çerkez ${ }^{131}$, Ivlati, Assi, Alan ${ }^{132}$, Avar ve Kumin ki bunların hepsi Tatar dilinde ${ }^{133}$ birbirleriyle temas kurar ${ }^{134}$. $\mathrm{Bu}$ ülkenin güneyinde Kafkas dağları vardır ve hayranlık uyandırıcı, yüksek ve geniş bir alana yayılmıştır. Ayrıca burada pek çok birbirinden farklı halklar ve diller, hatta canavarlar yaşar. Bunlara Monacli derler ${ }^{135}$ ki insanların bedenlerinden beslenirler. Köpeğe benzer insanlardır, yani bir yarısı köpek bir yarısı da insandır ${ }^{136}$. Köpekler kadar hızlı kaçarlar, yine de avlanmaları için köpeklere ihtiyaç yoktur, çünkü karaca kadar hızlıdırlar ve (ancak?) kendilerini avlarlar ${ }^{137}$.

Dindar kimselerden duyduğuma göre dağların ötesinde birbirinden farklı elli dil ve kültür bulunmaktadır. İbadetlerinin nasıl olduğu konusunda bilgi

${ }^{129}$ Türk ve Moğolların hayvanlarını yabani hayvanlardan koruması ve bereket getirmesi için çeşitli idoller kullandıklarından Plano Carpinili Johannes de bahseder. Bk. C. Dowson, a.g.e., s.9.

${ }_{130}$ Altın Orda Hanlığı zamanında insanların kıtlık nedeniyle çocuklarını satmaları diğer kaynaklarda da geçer. Bu konuda bk. A.Yu. Yakubovskiy, a.g.e., s.68, 69; N. di Cosmo, a.g.m, s.398, 399. Johannes'in çağdaşı Edige zamanında bu bir süre yasaklanmışsa da tarih sahnesinden çekilmesinden sonra devam etmiştir. Bk. G. Vernadsky, a.g.e., s.337.

${ }^{131}$ Metinde Tarcazi.

132 İki halkı farklı adlarla zikretse de Alan ve As kullanımı aynı halkı ifade etmekteydi. İranî bir kökene sahip olan Alanlar, Kafkasların önemli halklarından birisi olarak Kafkasya'da, Avrupa'da ve hatta Anadolu'da Doğu Roma'nın paralı askerleri olarak boy göstermişlerdir.

${ }^{133}$ Yazar Tatarca olarak ifade etse de bahsi geçen dilin Türkçe olduğu muhakkaktır.

134 Clavijo'nun Ermenilerin Türkçe konuştuklarından bahsetmesi, Johannes'in ilgili kaydını doğrulamaktadır. Bk. Clavijo, a.g.e., s.77. Türkçe'nin Kafkaslarda ortak dil olarak kullanılmasına ilişkin bk. U. Tavkul, "Codex Cumanicus ve Karaçay-Malkar Türkçesi”, Türk Dünyası Dil ve Edebiyat Dergisi, C.15/2003, s.47, 48.

${ }^{135} \mathrm{Bu}$ kelime L. Tardy tarafindan kesin olarak açıklanmıştır. Tardy kelimenin aslında Plinius'un tarihinde kullanıldığı haliyle Mononoli olduğunu ifade eder ki burada onlar benzer bir halk olarak tanımlanmışlardır. Bk. L. Tardy, a.g.m, s.104/68dp.

${ }^{136}$ Plano Carpinili Johannes'in seyahatnamesinde de bu efsanevi varlıktan bahsedilir. Bk. C. Dowson, a.g.e., s.31, 58. Ancak ondan kısa süre sonra bölgeye gelen ve Johannes'ten daha entelektüel bir kimse olan Rubruklu Willem, Kafkaslarda onları soruşturduğunu, ama hiçbir netice alamadığını alaycı bir üslupla dile getirir. Bk. Ruysbroeckli Willem, a.g.e., s.142.

${ }^{137}$ In cursu veloces ut canes, neque in venacionibus indigent canibus quia ipsi velociores sunt cervis et capiunt ipsos. 
sahibi olmadığımı belirtmeliyim. Bu dağların arası Usta'nın Tarih'inde ${ }^{138}$ dediğine göre Büyük Aleksander'ın İsa karşıtının ortaya çıkana kadar buradan çıkmamaları için hapsettiği Gog ve Mogoglar için kapatılmıştır. Buradakilerin fikrine göre (bu yapı) sağlam bir şekilde (onları) muhafaza etmektedir. Dağ ile güneydeki Hazar denizi arasındaki duvarları ve demirden kapısı (bugün de) görülmektedir ${ }^{139}$. Buras1 ve elbette Hazar denizi ile ilgili olarak söylenilenlerin çoğunu gördüm. Tatarya'da bizim pek çok din adamımız vardır ve dinimiz ile ve Katolikliği güçlü bir şekilde muhafaza ederler ${ }^{140}$. Burada islah edilmemiş vahşiler bulunur ve ne gösterişli bir sanata ne de bir taraflarını örtmek için pahalı bir kıyafete sahiptirler. Yemeklerinde ne ekmek yer ${ }^{141}$ ne de şarap içerler, sadece et yer ve süt içerler. Asilleri at eti

${ }^{138}$ Yazar burada Petrus Comestor'un Historia Scholastica adlı eserinden bahsetmektedir. Bk. A. Kern, a.g.m, s.109; L. Tardy, a.g.m, s.105/74dp.

139 Tarihi eserlerde Kafkaslarda iki farklı geçitten bahsedilir. Bunlardan birisi Daryal geçidi, diğeri ise Derbend geçididir. Yazarın burada bahsettiği Derbend geçidi, Sasani hükümdarı I. Anuşirvan (531-579) zamanında inşa edilmişse de sonrasında geçidin Büyük İskender tarafından inşa edildiği bir edebiyat geleneği olarak asırlarca devam etmiştir. Bk. A.R. Anderson, "Alexander at the Caspian Gates", Transactions and Proceedings of the American Philological Association, Vol.59/1928, s.154. Bu konuda yazarın daha kapsamlı olan şu çalışmasına da bk. A.R. Anderson, Alecander's Gate, Gog and Mogog, and the Inclosed Nations, Cambridge University Press, 1932. Bu daha sonra apokaliptik olarak anılan metinler içine de girerek İskender'in, dünyanın sonu geldiğinde yaşadıkları yerden çıkacak olan Gog ve Mogog'ları demirden bir duvarın ardına hapsettiği şeklinde bir inanca dönüşmüştür. Esasen bu inancın İskitler'in Orta Doğu'ya düzenledikleri ve Filistin'e kadar uzanan seferlerinin bir yankısı olarak yayıldığı ve dini bir inanış haline geldiği anlaşılmaktadır. Bk. E.D. Philips, "The Scythian Domination in Western Asia: Its Record in Histoy, Scripture and Archeology", World Archeology, Vol.4/No2, Oct. 1972, s.134. Bu metinler P. Jackson'un daha önce işaret ettiği gibi (P. Jackson, "Medieval Christendom's Encounter with the Alien", Historical Research, Vol.74/2001, s.348.) Batılıların doğu halklarını tanımlamak için kullandıkları pratik bilgiler olarak zamanın entelektüel dünyasında yerini almıştır.

${ }^{140}$ Yazar burada Kırım ve Saray kentlerinde kurulu bulunan piskoposluk merkezlerinden bahsetmektedir. Saray'daki piskoposluğunun daha 1315 'te etkin olduğu görülmektedir ki bu sırada başında Fransiskenlerden Stefan adlı bir din adamı bulunuyordu. Altın Orda'da bundan sonraki dönemde 12 Fransisken kilisesinin varlığı kaynaklara yansımıştır. Ancak onlar Rus din adamları karşısında etkinliklerini en azından Saray'da kaybetmişlerdir. Bk. M.D. Poluboyarinova, Russkiye Lyudi v Zolotoy Orde, Akademi Nauk SSSR, Moskva, 1978, ss.26-34; I. Kamalov, a.g.e., s.222, 223. Ancak Katolikler varlıklarını Kırım'da korumayı başardılar. Bunda Kırım'da Venedik ve Ceneviz kolonilerinin büyük bir payı bulunmaktaydı. $\mathrm{Bu}$ din adamları sadece kiliselerinde din işleriyle meşgul olmakla kalmıyor etkin bir misyonerlik faaliyetini de icra ediyorlardı. İşte Codex Cumanicus adlı Kıpçak Türkçesindeki kitap, böylesi bir ortamda yazılmışıı. Bu eser, genel olarak incelendiğinde kitabı hazırlayan kimselerin Kıpçak Türkçesi'ne büyük bir hâkimiyeti olduğu dikkati çekmektedir.

${ }^{141}$ Ekmeğin Türk ve Moğol mutfağında önemli bir yer tutmadığı diğer kaynaklarda da ifade edilir. Bk. C. Dowson, a.g.e., s.16; Simon de Saint Quentin, Bir Keşişin Anılarında Tatarlar ve Anadolu (1245-1248), çev. E. Özbayoğlu, Daktav yay., Antalya, 2006, s.12, 20; Aknerli 
yer ve öğle yemeklerinden sonra atın sütünü içer ${ }^{142}$. Bunu mayalanmamış ve yağsız olarak yaparlar. Denizden pek çok balık yakalarlar ${ }^{143}$. Şimdilerde belirledikleri herhangi bir İmparatora sahip değillerdir, ancak bazı tiranlar hüküm sürer. Onların İmparatoru, Timur ${ }^{144}$ ile karşılaşınca kaçmıştır ${ }^{145}$ ve şimdi ülkede başka tiranlar vardır ${ }^{146}$.

\section{7. Çerkezler}

Dağın etekleri ve Büyük denizin yakınlarında Ziquia veya Çerkezya ${ }^{147}$ olarak anılan bir ülke bulunur. Küçük efendileri hariç bir krala sahip değillerdir. Çoğu kendilerinin idare ettikleri çiftliklerinde yaşar ve başka bir şeyle ilgilenmez. Herhangi bir kente sahip olmayıp (ülkelerinde) küçük ovalar ve Kafkas dağlarına kadar uzanan yüksek dağlar vardır. Ülkeleri iki kısma ayrılır. Bunlar Kara ve Beyaz Çerkezya'dır ${ }^{148}$. Kara ile kasıt deri(deki gibi bir renk) değildir. Dağlarda yaşayanlar kara, çiftliklerde ve deniz kıyılarında yaşayanlar ise beyaz olarak anılır ${ }^{149}$. Karalara hiç kimse ulaşamamıştır. Onlar da dağlarından, nadiren tuz edinmek için gelenler müstesna, çıkmazlar.

Grigor, a.g.e., s.23; Jean de Joinville, Bir Haçlının Hatıraları, çev. C. Kanat, Vadi yay., Ankara 2002, s.182; Ibn Battuta, s.466; A.N. Kurat, a.g.e., s.E.34.

${ }^{142}$ Türk ve Moğol beslenmesinde kımızın ne kadar büyük bir öneme sahip olduğu diğer yazarlar tarafindan da teyit edilir. Bk. Ibn Battuta, s.466, 469, 476, 478, 479.; C. Dowson, a.g.e., s.17; Simon de Saint Quentin, a.g.e., s.20, 86; Marco Polo, Dünyanın Hikâye Edilişi, C.I, çev. I. Ergüden, İthaki yay., İstanbul 2003, s.173 Jean de Joinville, a.g.e., s.182; A.T. Özcan, "Chronica Maiora'da Moğol İmajı", Tarih İncelemeleri Dergisi, C.XXVII/II, s.434. Kımızın Moğol besininde ne denli önemli bir yer işgal ettiği Rubruklu Willem'in seyahatnamesinde de bulunur. Ancak onu diğerlerinden ayıran kımızın hazırlanmasıyla ilgili detayl1 sayılabilecek bilgiler vermesidir. Bk. Ruysbroeckli Willem, a.g.e., s.95-97. Türk ve Moğollarda kımız kullanımına dair bk. P. Pelliot, "A Propos des Comans", Journal Asiatique, Tom.15, s.169, 170.

${ }^{143}$ Yazarın ifadeleri Kırım'daki balık ticareti ile ilgilidir. Bölgedeki balık ticaretine dair bk. E.S. Zevakin, N.A. Pençko, a.g.m., s.79, 81-83; A.N. Kurat, a.g.e., s.51, 52.

${ }^{144}$ Metinde Themurbey.

145 Toktamış, Terek’te Timur karşısında ağır bir yenilgi alınca önce Bulgar topraklarına, ardından Kırım'a kaçmışsa da tutunamamış, Altın Orda tahtını ele geçirmek için Litvanya kralıyla işbirliği yapmışsa da sonunda yenildi. 1405 'te ise tarih sahnesinden çekilmiştir. Bk. A.Yu. Yakubovskiy, a.g.e., s.184-190.

${ }^{146}$ Burada yazar Toktamış'ın Altın Orda topraklarından çekilmesinden sonra hâkimiyeti ele alan Timur Kutluğ ve Edigey’den bahsetmektedir. Toktamış'ın Terek yenilgisinden sonra Altın Orda'daki durum hakkında bk. A.Yu.Yakubovskiy, a.g.m, s.184-203; I.M. Mirgaleev, Politiçeskaya Istoriya Zolotoy Ordı Perioda Pravleniya Toktamış Hana, Kazan, 2003, ss.141-155.

${ }^{147}$ Metinde Tharquesia.

${ }^{148}$ Metinde Tarcasi.

149 Burada ifade edilenler Karaçaylardır. Nitekim daha başka kaynaklarda da onlar Kara Çerkez olarak anılırlar. Bk. L. Tardy, a.g.m, s.105/79dp. 
Kendilerine özgü bir alfabeleri ve dilleri vardır. Dinî olarak neredeyse tamamı, bazı ibadet ve bayramlarında Grekleri takip eder ${ }^{150}$. Pek hesap edilemeyecek kadar az olan diğerleri ise kendi düzenlerine ve ibadetlerine uyar. Paskalyadan önceki perhizi 50 gün kutlar ve geliş ${ }^{151}$ ile altıncı haftay ${ }^{152}$ şenlendirir, diğerlerine önem vermezler. Bayramları, kiliseleri ve idolleri Greklerinki gibidir. Büyük Bayramda ve Pazar günlerinde hayvan kurban eder, bölüşür ve yerler. Hayvanın başını fakir ya da yaşlılara verir veya ya yukarıya (bir yerlere) ya da ağacın dalına ruhların hakkı diyerek koyarlar $^{153}$. Ağacı kilisenin yakınına diker, en üstüne Tanrının ağacı dedikleri bir haç koyar, dallarına da değişik işaretler çizer ve hayvanın kafasını yerleştirirler ${ }^{154}$. Papazları yoktur. Eşe sahip olmayanlar onlar arasında barınamadıklarından din adamlarının eşleri vardır. (Yaşadıkları diyarda) Pek çok haydut ve hırsız vardır. Bir köyden çıkıp da başka bir köye gider, kızları ve erkekleri kaçırırlar. Ya da yapabiliyorlarsa çalar ve deniz kıyısındaki tüccarlara satarlar. Tatarlar gibi kendilerini sattıklarından zavallı kimselerdir ${ }^{155}$. Fakat iyi bir şeye sahiplerdi ki kilisenin ve Tanrının ağacının yakınlarında bir çember oluşturur ve çember içindeki hiçbir kimse bir birine dokunmaya cüret edemez. Fakat dışında ilk dokundukları onların olacaktır. Özellikle gemilerin çarpıştığ deniz kıyısındakiler için (bunları) kendilerine Tanrının gönderdiklerini söyler ${ }^{156}$ ve (buldukları insanları da) domuz gibi satarlar ${ }^{157}$.

Kadınların büyücü olduklarını ve kendilerini bu yeteneğe adadıklarını iddia ederler. (Bu kadınlar) rüzgâr estirir ve denizi kabartırlar. Böylesi durumlarda gemiler birbirlerine girer çünkü donanımlı limanları yoktur. Ben buralarda bulunduğumda bunların doğruluğunu gördüm. Bu sihirli yetenekle denizi kabartırlar, özellikle de geceleri. Ancak biz dualar ve azizlerin yardımı ile bunları yenmişizdir. Burada seksen kişiydik $\ldots{ }^{158}$ sonunda

\footnotetext{
${ }^{150}$ Kalkaşandî de Çerkezlerin büyük kısmının Hıristiyan olduğunu bildirir. Bk. D. Ayalon, "Cerkes" (Memluk Period), Encyclopedia of Islam 2, Vol. II, Leiden, 1991, s.23.

${ }^{151}$ Adventum.

${ }^{152}$ Sextam fariam

${ }^{153} \mathrm{Bu}$ adet ile ilgili olarak bk. L. Tardy, a.g.m, s.105, 106/82dp.

${ }^{154} \mathrm{Bu}$ adet ile ilgili olarak bk. L. Tardy, a.g.m, s.106/83dp.

${ }^{155}$ Çerkez ülkesinden yapılan köle ticaretine ilişkin bk. M. Bala, a.g.m, s.380.

156 Çerkezler sadece deniz kıyısına vuran gemileri değil, aynı zamanda kıyıya yanaşan gemileri de yağmaladıklarına ilişkin elde pek çok delil vardır. Zamanındaki örneklerinden başka XVI. yüzyılda dahi Çerkezya kıyılarında korsanlık faaliyetleri önemli bir mesele olarak gündemi işgal etmiştir. Bk. E.S., Zevakin, N.A. Pençko, a.g.m., s.97, 98; M. Balard, a.g.e., s.157.

${ }^{157}$ Extra autem quod prius tetigerit suum erit et specialiter in maritimis ubi franguntur naves, et dicunt quod deus misit ipsis et vendunt hominem pro porco.

${ }^{158}$ Metnin bu kısmı boș bırakılmıştır.
} 
dediler ki: "Size karşı üstün gelemiyoruz, çünkü azizler sizlerle (birlikte bize karş1) savaşıyor. Geceleri Aziz Nikola'yl size ateşli ve bağlı bir şekilde yardım ederken görüyoruz. (Şimdi ise) Kurtulduktan aylar sonra Tanrıy anıyor ve topraklarındaki Aziz Nikola kilisesine gidiyoruz. Huzur içindeyiz" Çok güzel bir yaradılışa sahiplerdir ve kadınları çok güzeldir. Asilleri hariç erkekleri neredeyse çıplak gibi dolaşır.

Onların asillerinden biri Cenovalılara satılmıştı. Yeteneği ve hizmet etmekten muaf edilmesi sayesinde Dominiken tarikatına girdi. Sonunda bir kilisede arhiepiskopos oldu ve bu bölgenin apostol makamına oturdu. Burada uzun süre kaldı ve kendi halkından pek çok kimseyi (Hıristiyanlığa) döndürdü.

Kahire Sultanı bir köle olarak buradan Misır'a götürüldü ve kendinden önceki Sultanın ölümünden sonra Sultan oldu. Şimdi oğlu ondan sonra sultandir ${ }^{159}$.

Dediğimiz üzere onlar her türlü işler için kapasiteli bir halktır, fakat kendi ülkelerinde değil. Bu ülkenin batısında Karadeniz, kuzeyinde Tatarya, doğusunda Kafkas dağları ve güneyinde Gürcistan ${ }^{160}$ ve Aphazya ${ }^{161}$ vardır.

\section{Gürcüler}

Gürcistan ${ }^{162}$ büyük bir ülkedir, fakat bütün halde değildir. Aralarında büyük anlaşmazlıklar vardır. Dediğimiz gibi batısında Kafkas veya Elbruz dağlar ${ }^{163}$ ile başlar. Güneyinde Büyük Ermenistan ve İran, doğusunda Bakü veya Hazar denizi, kuzeyinde ise Tatarya bulunur. Bu krallık iki parçaya ayrılmıştır. Dış kısmı doğu tarafındadır ve Gürcistan olarak anılır. İç kısmı ise Aphazya olarak anılır. Bu ülkede tek bir kralın olduğu söylenir, ancak şimdi aralarında barış olmayan pek çok efendi tarafindan parçalara ayrılmış durumdadır. Onlar inançlı ve içten kimselerdir. Bundan ötürü de Katolik inancına geçmişlerdir. İsa'nın lütfu ile bu ülkenin pek çok bölgesinde Dominiken ve Fransisken makamları vardır. Halkın büyük bir kısmı da (bu inanc1 devam ettirir).

\footnotetext{
${ }^{159}$ Burada Sultan Berkuk ve oğlu Farac'dan (1399-1412) bahsedilmektedir. Mignanelli'nin Ascensus Barcock başlıklı çalışmasında da Berkuk'un, Johannes'in kullandığı şekliyle Zichia'da yani Çerkezya'da doğduğu ve Kefe'de satılarak Mısır'a getirildiği ifade edilir. Bk. W.J. Fischer, "Ascensus Barcoch (I) A Latin Biography of the Memluk Sultan Barquq of Egypt (D.1399) Written by B. de Mignanelli in 1416", Arabica, Tome VI, Fasc.I/1959, s.64. ${ }^{160}$ Metinde Ioriania.

${ }^{161}$ Metinde Apcasia.

${ }^{162}$ Metinde Ioriana.

${ }^{163}$ Metinde Album.
} 
(Gürcistan'da) çok büyük günahlar işlenmiş ${ }^{164}$-özellikle de kralları tarafından- ve pek çok kâfirlikler yapılmıştır. Bundan ötürü Tanrı onları cezalandırmış ve Timur yoluyla kırbaçlamıştır. $O$, onların ülkesine üç kere girdi ${ }^{165}$, burayı tarumar etti, çok büyük katliamlarda bulundu ve halkı esir etti. Kiliseleri ve kutsal alanlar ile inşa edildiğinden beri ne dünyada hiçbir kimsenin ne de Sarasinlerin benzerini inşa edemediği Aya Sofya'yı andırır 30 göz alıcı yapıyı yok etti ${ }^{166}$. Onların yaşlı kralı ${ }^{167}$ onun tarafindan (=Timur) kraliçesi ${ }^{168}$ ve bir oğlu, ülkedeki yaklaşık 100.000 insanla birlikte esir edildi. Bizim de pek çok Hıristiyanımız da onlarla birlikteydi.

$\mathrm{Bu}$ ülkenin genişliği neredeyse 20 günlüktür. Fakat kalabalık bir şekilde yerleşim tutulmamıştır. Burada Gürcüler, Ermeniler, Sarasinler, Yahudiler ${ }^{169}$ gibi birbirinden farklı halklar ve tüccarlar bulunur. Ülkenin sınırlarında Duelli ${ }^{170}$, Alanlar, Assiler ${ }^{171}$ vardır. Bu ülkede uzun zamanlar boyunca Dominiken ve Fransiskenler dua etmiş, pek çok kimseyi (Hıristiyanlığa) döndürmüş ve pek çok makama sahip olmuşlardır. Bu ülkenin içinde Kura ${ }^{172}$ adı verilen geniş bir ırmak akar ve Hazar denizine dökülür. (Irmağın) Kaynağı Dicle ve Fırat' $1 n^{173}$ doğduğu Büyük Ermenistan dağlarındandır.

\section{Lezgiler}

Gürcistan'ın doğusunda Lezgiler ${ }^{174}$ bulunur. Kendisine özgü dilleri vardır. İskender'in inşa ettiği ve Gog ile Mogogları hapsettiği surların

\footnotetext{
${ }_{165}^{164}$ Sodomite.

165 Timur Gürcistan'a toplamda altı saldırı gerçekleştirmiştir. Ancak bunlardan üçü ziyadesiyle mühimdir. Bu seferlerle ilgili olarak bk. K. Paydaş, "Timur'un Gürcistan Seferleri”, Firat Üniversitesi Sosyal Bilimler Dergisi, C.16/S.1, 2006, ss.419-437. Ayrica bk. İ. Aka, a.g.e., s.21, 25, 31. L. Tardy ise Gürcistan'ın sekiz kez saldırıya uğradığını belirtir. Bk. L. Tardy, a.g.m, s.109/120dp.

${ }^{166}$ Gürcistan'ın uğradığı saldırı ve neticeleri hakkında bk. H.R. Roemer, "Timur in Iran", Cambridge History of Iran, ed. P. Jackson, L. Lockhart, Cambridge UP, 2006, s.59.

${ }^{167}$ Burada V. Bagrat'tan (1360-1395) bahsedilmektedir. Fakat yazar onun İslamı kabul ettiği konusunda, muhtemelen dini propaganda adına, sessiz kalmıștır. Bk. Roemer, a.g.m, s.59. Oysa ki bu hadiseden bahseden Metsoplu Toma onun zorla Müslüman yapıldığından bahsederek bir çıkış yolu bulabilmişti. Bk. Toma Metsopski, a.g.e., s.15.

${ }^{168}$ Burada Trabzon prensesi Anna Comnena'dan bahsedilmektedir. Bk. Roemer, a.g.m, s.59.

${ }^{169}$ Kafkaslarda yaşayan Yahudilerden Rubruklu Willem de bahseder. Ruysbroeckli Willem, a.g.e., s.270, 271. Metsoplu Toma da onlara kısaca değinir. Bk. Toma Metsopski, a.g.e., s.15.

${ }^{170}$ Bugün de aynı adla anılan Gürcistan'ın dă̆ boylarından birisi. Bk. L. Tardy, a.g.m, s.110/ $130 \mathrm{dp}$.

${ }^{171}$ Allani ve Assi olarak iki ayrı halk olarak ifade ediyorsa da, yukarıda da ifade edildiği üzere, onlar tarihi kaynaklara Alan veya As adı ile geçen bir İranî halktır.

${ }^{172}$ Metinde Thur.

${ }^{173}$ Metinde Tigris ve Effrates.

${ }^{174}$ Metinde Lagzi.
} 
gözüktüğü dağlara yerleşmişlerdir. Burası aynı zamanda Hazar denizi ile dağlar arasında bulunan Porta Ferrea (=Demirkapı) olarak anılan kente çok yakındır. Burası çok dar bir geçittir. Hiçbir canlı, bu boğaz hariç ne dağ ne de deniz yoluyla burayı geçebilirr ${ }^{175}$. Bundan ötürü İranlılar buraya Derbend, yani dar kap1 veya kapalı kapı adını vermişlerdir. Bu görüşler efendi Scolasticum'da (=eserinde) bulunur. Ancak çağdaş kimseler tarafından da (yazılanların) gerçekliği söylenir ve surlar görülür. Aleksander'ın onları kapattığı ve hiçbir kimsenin buradan geçemediği ve çıkamamasıyla ilgili olduğu gibi.

Yaşayan hiçbir kimse onların yaşam tarzlarını ve adetlerini bilmez. Bununla birlikte onlarla karşılaşan bazı kimseler yaşamlarında hayret uyandıracak hikâyeler olduğunu söylerler. Mesela (anlatılanlara göre) tuza ihtiyaç duyar ve komşularının tuz koydukları dar geçide gelir ve (karşıllğında) hayvanlarını bırakır veya (onların bölgelerine) sürerler. Hiç kimseyle konușmadan böylelikle değiș tokuş ederler. Böylesi bir halk olan Lezgiler sanki hiçbir kanuna sahip değillerdir ${ }^{176}$. Bazıları Sarasinleri, bazıları Gürcüleri veya daha başkaları da Hıristiyanları takip eder ${ }^{177}$. Vahşi ve okçulukta becerikli bir halktır. Timur onların dağlarına veya çevresindeki bölgeye ulaşmak imkânı olup olmadığını merak etti ve 100.000 askerini buraya gönderdi. Ancak ormanlık bir alana geldiler ve çok zorluk çektiler. Bundan ötürü de adamlarına geri çekilmelerini emretti. Demirkapı'nın içinden buranın efendisiyle barış yapmadan geçemeyeceğini anlayınca da Büyük Tatarya'ya döndü ${ }^{178}$.

$\mathrm{Bu}$ dağlar ve yerleşimcileriyle ilgili daha pek çok şey söylenebilir, fakat şimdilik bu kısa bilgiler yeterlidir.

\footnotetext{
175 Yazar burada Demirkapı/Derbend adını kullanıyorsa da bahsettiği esasen Daryal geçidi olarak anılan geçittir. Latince kaynaklarda Demirkapı'dan Kafkas, Daryal geçidinden ise Hazar kapısı olarak iki farklı adla bahsedilir. Fakat bu adın Pliny'nin yakınmasına bakacak olursak (Portae Cancasiae magno errore multis Caspiae dictae) antik dönemde dahi birbirine karıştırılıyordu. Hataya düşen yazarlardan birisi de Jordanes’tir. V. yüzyılda kaleme aldığı Getica adlı eserinde yazar Lezgilerin Kafkas geçitlerini koruduklarını ifade eder. Bk. A.R. Anderson, a.g.m, s.145, 152.

${ }^{176}$ Et isti tales Lagzi sunt quasi nullius legis.

${ }^{177}$ Lazların dini durumuna ilişkin bk. Bk. R. Wixman, "Lezgh”, EI2, Vol. V, Leiden 1986, s.729, 730 .

178 Johannes'in bahsettiği hadise Timur'un 1399'da Karabağ'da kışladığında Gürcistan üzerine düzenlenmesini emrettiği, fakat kış koşullarından ötürü gerçekleşemeyen seferi akla getirmektedir. Zira Târîh-i Kebîr'de de ordunun 10 gün boyunca ağaç keserek yol aldığından bahsedilir. Bk. Caferî b. Muhammed el Hüseynî, a.g.e., s.6. Bu sefer ile ilgili olarak ayrıca bk. H.R. Roemer, a.g.m, s. 75 .
} 


\section{Ermenistan}

İran ve Bakü denizinin batısında büyük bir ülke olan Büyük Ermenistan bulunur ${ }^{179}$. Onların ibadetleri ve anlattıkları ile ilgili pek çok şey söylenebilir. Ancak şimdilik (aşağıdakiler) yeterlidir.

Burada Dominiken kardeşler tarafindan İsa'yı şereflendirmek ve dini onurlandırmak için yapılan dikkate değer bir din değiştirme faaliyetinden bahsedeceğiz. 1310 yılında veya civarında Doğuda Roma kilisesi ve ibadetlerine ilişkin hiçbir bilgi yoktu. Ancak söz konusu yıllarda bazı Dominiken kardeşler tüccarlarla beraber ilk önce İran ve Büyük Ermenistan'a geldiler, onların dinî hatalarını ögrendiler ve Katolik inancına göre vaaz etmeye başladılar. Bazıları onların dillerini öğrendi ve pek çok kimseyi (Katolik Hıristiyanlığa) döndürdü, özellikle de Ermenistan'dakileri. Bu dönemde 50'li yıllarda bir öğretmen bir okul kurdu ve zamanında kendi öğrencilerinden 600 kişiyi kendi tarzları ve ibadetleri hususunda eğitti. (...) Öğrenciler İran'daki Meraga ${ }^{180}$ kentine kadar gittiler ve Dominiken tarikatı kardeşlerinden saygıdeğer ve dindar Padiolu Bartholemeus'u buldular ki bu ülkeye ilk gelen kimse oydu. Söylenilene göre buradaki kentte bir kilise ve pek çok Katolik bulunuyordu. (...). Bu mucizevî haberleri alan ve büyük bir memnuniyet duyan Papa XII. Johannes bu ülkeyle ilgili gayet iyi bilinen pek çok emirname gönderdi. Hemen ardından da Sultaniye kilisesi emirnamelere göre Türkiye'den ${ }^{181}$ Hindistan ve Etyopya'ya kadar uzanan tüm Doğunun bir arhiepiskoposluğu olarak kuruldu ${ }^{182} .(\ldots)^{183}$

\footnotetext{
${ }^{179}$ Büyük Ermenistan, Selçuklular zamanında Türklerin gelmesinden önce, Hazar denizi sahillerinden Sivas'a kadar uzanan bölgeyi kapsıyor ve güneyde de neredeyse Musul'a kadar iniyordu. Bununla birlikte Türklerin ortaya çıkmasından sonra sınırları doğuya doğru daralmaya başladı. Nitekim eserlerini XIV. yüzyılın hemen başlarında yazdıran Marco Polo ve Korykoslu Hetum Turchia olarak andıkları Türkiye sınırlarını Erzurum'a kadar geniş̧letmişlerdir. $\mathrm{Bu}$ sınırlar ilerleyen yıllarda daha da genişlemiştir. Nitekim XVI. yüzyıldaki Avrupalı bilginler için Türkiye, günümüzün sınırlarını tamamen içine aldığı gibi, Arabistan çöllerine ve bu arada Ege adalarına da yayılıyordu. Türkiye adının yaygınlık kazanmasına paralel olarak Ermenistan gibi diğer ülkeleri coğrafya literatüründeki sınırlarının daralmasına ilişkin bk. A.T. Özcan, "XVI. Yüzyıla Kadar Türkiye ve Türkmenya Adının Batı Dünyasındaki Kullanımı ve Sınırları", Türkiyat Mecmuası, C.22, s.63-82.

${ }^{180}$ Metinde Marga.

${ }^{181}$ Metinde Thurkia.

${ }^{182}$ Sultaniye arhiepiskoposluğu 1318'de kurulmuştur. Bk. F. Schmeider, "Christians, Jews, Muslims-and Mongols: Fitting a Foreign People into the Western Christian Apocalyptic Scenario", Medieval Encounters, Vol.12/2, 2006, s.293. Makamın ilk sahibi belli değilse de 1322 'de William Adam adlı muhtemelen bir İngiliz buraya tayin edilmişti. Bk. M.W. Baldwin, "Missions to the East in the Thirteenth and Fourteenth Centuries", A History of the Crusades, ed.K.M. Setton, University of Winconsin Press, 1985, s.505.
} 


\section{1. İran}

$\mathrm{Bu}$ ülkenin güneyinde ve doğusunda büyük bir ülke olan İran bulunur. İran krallığı iki kısma ayrılır, ancak söylenirken tek bir imparatorluk olarak ifade edilir ve İranlılar ile Medlerin İmparatoru olarak söylenir. Bu ülke Küçük Hindistan ile başlar hiç kesintisiz batıda Büyük Ermenistan'a kadar uzanır. Bu ülkenin ve tüm bölgelerin idaresi kendi İmparatorlarına aittir. Din olarak da burası Sultaniye arhiepiskoposluğuna bağlıdır ki buranın en değersizi şimdi benim ${ }^{184}$. Şu anda buranın hâkimi Timur'dur. (Bir zamanlar) bu ülkenin tamamını hatta Asur'un 120 bölgesini kendi imparatorları idare ediyormuş. Ancak şimdiki İmparator öbürünün kaçmasıyla Timur olmuştur ${ }^{185}$. Timur ülkenin pek çok kısmını nefesini kesercesine yok etmiştir. Burada krallığın en kalabalık ve meşhuru Isfahan ${ }^{186}$, bir zamanlar Susis olarak anılan Ester kitabına göre büyük Asur şenliklerinin yapıldığ 1 Tebriz $^{187}$ kentleri bulunmaktadır. Orada aynı zamanda İmparatorluğun başkenti olan Sultaniye kenti bulunmaktadır ${ }^{188}$ ki burası Papa XII. Johannes

${ }^{183}$ Bundan sonra Sultaniye'deki din adamlarının Hıristiyanlığı yayma faaliyetleri hakkında genel bazı bilgiler verilerek ne kadar başarılı oldukları anlatılır.

${ }^{184}$ Burada yazar zamanın nezaket kurallarına uyarak kendini alçaltarak makamın kendisine ait olduğunu ifade etmektedir.

${ }^{185} \mathrm{Bu}$ abartılı ifadede kastedilen kişinin Muzefferî hükümdarı olduğu Metsoplu Toma'nın bir kaydından anlaşılmaktadır. Bk. Toma Metsopski, a.g.e., s.12, 13. Toma, Şah Mansur adını zikretse de asıl mücadele Zeynelabidin tarafindan yürütülmüş ve İran onun çekilmesinden sonra Timur'un eline geçmiştir. Bk. İ. Aka, Mirza Şahruh ve Zamanı, s.14; H.R. Roemer, a.g.m, s.60.

${ }^{86}$ Metinde Ispahan. Timur zamanında Isfahan en önemli İran kentlerinden birisiydi. Timur'un torunu Rüstem de bu kentte valilik yapmıştır. Timur zamanında İsfahan ile ilgili olarak bk. V.V. Bartold, "İstoriko-Geografiçeskiy Obzor İrana", Soçineniye, Tom.VII, İzdatelstvo Nauka, Moskva, 1967, s.172.

${ }^{187}$ Metinde Thauris. İran'ın en önemli kentlerinden birisi olan Tebriz İlhanlılar zamanında önemli bir ticaret ve kültür merkezi olarak Moğol işgalinden sonra yeniden canlanmıştır. İlhanlılar zamanında Tebriz için bk. K. Jahn, "Tebriz: Doğu ile Batı Arasında bir Ortaçağ Kültür Merkezi”, çev. İ. Aka, Tarih Araștırmaları Dergisi, C.XIII/S.XXIV, 1979-1980, ss.59-79; V.V. Bartold, a.g.e., s.205-208; N. di Cosmo, a.g.m, s.411; R. Prazniak, "Tabriz on the Silk Roads: Thirteenth Century Eurasian Cultural Connections", Asian Review of World Histories, Vol.I/2, 2013, s.169-188; J. Preiser-Kapeller, "Civitas Thauris: The Significance of Tabriz in the Spatial Frameworks of Christian Merchants and Ecclesiastics in the 13th and 14th Centuries", Politics, Patronage and the Transmission of Knowledge in 13th-15th Century Tabriz, ed.J. Pfeiffer, Brill Publishing, Leiden-Boston, 2014, s.251-299. Timurlular zamanında kent önemini daha da artırdı. Burası geniş bir bölgenin idari merkezi haline getirildiği gibi Clavijo'nun verdiği bilgiler ticari açıdan da epeyce geliş̧miş olduğuna işaret eder. Seyyah kentteki pazarlardan, mimarisinden, bașta ipek olmak üzere sanayiden ve Cenovalı tüccarların etkinliğinden hayranlıkla bahseder. Bk. Clavijo, a.g.e., s.81, 82 .

${ }^{188}$ Yazar kenti İmparatorluğun başkenti olarak ifade ediyorsa da bu ancak İlhanlılar zamanı için doğrudur. 
tarafından tüm doğunun metropolitliği ilan edilmiştir. İran sınırında Buhara ${ }^{189}$ ve Timur'un oturduğu, bir zamanlar küçük ancak şimdi çok büyük olup her açıdan zengin, azametli ve tahkimatlı Semerkant ${ }^{190}$ kentleri vardır. Doğunun tüm hazinesi buraya gönderilir.

\section{Mezopotamya}

İran'ın güneyinde doğuya doğru Kaldea ${ }^{191}$ bulunur. Geniş Kaldea krallığ 1 kuzeyde Meraga olarak anılan bir kentle başlar ve güneyde Okyanus denizine (=Basra körfezi) kadar devam eder. Zamanın en büyük kenti Bağdat'tır ${ }^{192}$. Firat'ın yukarılarına kadar böylesi kent bulunmaz. Bu krallıkta pek çok ova, küçük dağlar ve farklı noktalardan gelen küçük pınarlar vardır. Burada Araplar, Kaldaniler, Süryaniler, Nesturiler, Ermeniler ve Katolikler gibi farklı milletten insanlar bulunur. Bağdat'ta Katoliklerin sayısını artırmış olan Katolik kardeşlerden birisinin yanına gitmiştim.

$\mathrm{Bu}$ krallığın yakınlarında Suriye'nin ${ }^{193}$ yukarı kısımlarında küçük bir bölge veya krallık bulunur. Med krallarının kentinin yakınlarında olan bu kent Mardin ${ }^{194}$ olarak anılır. Mardin' in yakınlarında da Urfa ${ }^{195}$ ve şimdilerde Musul $^{196}$ olarak anılan İsa'ya (mektup) gönderen Kral Abagaron'un ${ }^{197}$ kenti bulunur. Buranın ahalisinin büyük bir kısmı Süryani'dir ve pek çok yerde makamları ve Katolik ${ }^{198}$ dedikleri patriklikleri bulunur. Latinlerden çok etkilenmişlerdir. Bunların büyük bir kısmı ilk önce Türkmenler, ardından da Timur tarafından harap edilmiştir. Dilleri ve alfabeleri kendilerine özgüdür. $\mathrm{Bu}$ ülkede Arapça ve Farsça da konuşulur, (bunlar) din olarak Sarasindirler (=Müslümandırlar).

\footnotetext{
${ }^{189}$ Metinde Bukara.

190 Timur zamanında Semerkant'ın detaylı denilebilecek bir tasviri Clavijo tarafindan yapilmıştır. Bk. Clavijo, a.g.e., ss.149-149-154.

${ }^{191}$ Metinde Caldea.

${ }^{192}$ Metinde Baldat.

${ }^{193}$ Metinde Sirie.

${ }^{194}$ Metinde Meldin.

${ }^{195}$ Metinde Edissla.

${ }^{196}$ Metinde Mosil.

${ }^{197}$ Burada Urfa hâkimi IX. Abgar (179-216) ifade edilmektedir. O, İsa'nın çağdaşı olmasa da daha sonraki teolojik edebiyatta onun İsa ile mektuplaştı̆̆ 1 ve Hıristiyanlığ krallardan birisi olduğuna inanılmıştır. Bk. W. Barthold, İslam Medeniyeti Tarihi, Akçağ yay., Ankara, 2004, s.38.

198 Metinde Cathelech.
} 


\section{Kürdistan}

Medya veya Partya'nın bir kısmı olarak İran'ın güneyinde Kürdistan ${ }^{199}$ bulunur ${ }^{200}$. Büyük bir ülkedir. Kendilerine özgü dilleri Farsça' ya çok benzer, bazıları da Ermenice konuşurlar. Bunlardan çoğu Ermeni ve Süryani Hıristiyanlığını benimsemişlerdir. Burada ayrıca bizim Katoliklerimiz ve kardeşlerimiz de bulunmaktadırlar.

\section{Hıristiyanlık ve İslam}

Bu kayıtların sonunda çok önemli bir rol üstlenmiş olan Hıristiyanların ve Sarasinlerin karşılaştırması yapılmıştır. $\mathrm{Bu}$ görüşlere göre Sarasinler ve Hıristiyanlar pek çok bölgeye, geniş bir alana ve dünyanın üç kısmına yani Asya'ya, Avrupa'ya ve Afrika'daki yerleşimcilere veya burayı ellerinde bulunduranlara hâkim durumdadırlar. Görüş bildirenlerin aksine pek çok kaynağa ve anlatıya (doğrudan) sahibim. Öncelikle çoğu bölge ve krallığ dikkate almamışsam da şu açıktır ki çok sayıda ülke gördüm ve zamanımızın saygın inançları hakkında bilgiler edindim.

Bazı bölgelerde ve büyük ülkelerde çok sayıda Hıristiyan Sarasin (=Müslüman) olmuştur. Bazı bölgelerde de bu kitabın aşağıdaki kısımlarında bildirildiği üzere, Hıristiyanlar birbirinden ayrışmıştır. Özellikle de Büyük Tatarya, Büyük Ermenistan, Küçük Asya yani Türkiye, Suriye'nin içleri ve diğer bölgelerde. Bunun aksine, az bir sayıdaki Yahudiler hariç tutulacak olunursa sadece bizim Hiristiyanlarımızın tamamı tek bir din etrafinda toplanmış ve tek bir kilisenin çatısı altına girmişlerdir.

\footnotetext{
199 Metinde Curdistan.

${ }^{200}$ Kürdistan tabiri tarihi kaynaklarda ilk kez Sultan Sancar zamanında bir bölge tesis etmesiyle ilgili olarak karşımıza çıkar. Sancar'ın Kürdistan bölgesi Hamedan'ın kuzeyindeki bir sahayı içine alıyordu ve başkenti de Bahar adlı bir yerleşim birimiydi. Bu bölge bu hali ile Azerbaycan ile Luristan arasındaki sahayı işgal etmekteydi ve Hamdullah Müstevfi'ye (ö.1349) göre 16 yerleşim birimine sahipti. Ancak bu adın genel bir coğrafi ad olarak kullanılmadığı, Şerafeddin Yezdî’nin Zafernâmesinde geçmemesinden anlaşılmaktadır. Diğer Arap kaynaklarında da bölgeden Cibal adı altında bahsedilir. Bk. Th. Bois, "Kurdistan", EI2, Vol.V, Leiden, 1986, s.439. Bununla birlikte en azından bazı yazarların bu adı tercih ettikleri de dikkati çeker. Bk. Nizamüddin Şâmî, a.g.e., s.158, 289, 290; Caferî b. Muhammed el Hüseynî, a.g.e., s.39, 41. Bunun yanı sıra Timur'un Yıldırım Bayezid'a gönderdiği 1395 Şubat tarihli fermanda da Kürdistan, İran'da yer alan bölgelerden biri olarak zikredilir. Bk. Z.V. Togan, "Vostoçno-Evropeyskaya Politika Timura", Zolotoordınskaya Tsivilizatsiya, Vıp. III/2010, s.219. Fermanda Kürdistan adı altında hangi bölge ifade edildiği belli değilse de burası, Clavijo'nun seyahatnamesinde verdiği bilgilerden hareketle Sultaniye'nin güneyindeki dağlık alan olduğu anlaşılmaktadır. Bk. Clavijo, a.g.e., s.86. Ortaçağ' da Kürdistan ile ilgili olarak bk. V.V. Bartold, a.g.e., s.189-191.
} 
Ne kadar bir toprak parçasını gözden kaçırdım (bilemiyorum), ancak doğrulukla diyorum ki bir yerde gördükten sonra bir diğerinde 30 gün kadar tek bir köy ve 10 gün kadar tek bir kentle karşılaşılmaz. Doğruluğu sabittir ki bu diyarda erzak günlerce taşınır. Burada tek bir krallığımız bile yoktur. Bunun aksine Avrupa'da Hıristiyanların bölgeleri şaşkınlık uyandıracak kadar kalabalık ve yerleşimle doludur. (Seyahat sırasında) her gün birden fazla kent ve bir köyle karşılaşılır. Ve şu sabittir ki hiçbir kimse erzakını yanında taşımaz, çünkü ihtiyaç duyduklarını her yerde bulabilir. (... $)^{201}$.

Böylelikle benim, Sultaniye ve tüm Doğunun Dominiken tarikatı kardeşlerinin arhiepiskoposu Johannes'in, dindarlarımız ve din doktorası sahiplerinin bilgisi için 1404'te hazırlanan küçük çalışmam burada sona eriyor. (...) Tanrıya şükürler olsun.

${ }^{201}$ Ülkelerin kalabalık oluşuna dair bazı notlar ihtiva eder. 


\section{KAYNAKÇA}

ABU-LUGHOT, J.L., Before European Hegemony The World System AD. 12501350, Oxford University Press, 1989.

AİGLE, D.; "The Letters of Eljigidei, Hülegü and Abaqa: Mongol Overtures or Christian Venteiloquism?", Inner Asia, 7/2005, ss.143-162.

AKA, İ.; "Timur Sadece bir Asker mi idi?", Makaleler, C.II, haz. E.S. Yalçın, Ş. Gedikli, Berikan yay., Ankara, 2005, ss.113-130.

AKA, İ.; "Timur'un Ankara Savaşı (1402) Fetihnamesi”, Makaleler, C.I, haz. E.S. Yalçın, Ş. Gedikli, Berikan yay., Ankara, 2005, ss.133-170.

AKA, İ.; "Timur'un Ölümünden Sonra Doğu Anadolu, Azerbaycan ve Irak-1 Acem'de Hakimiyet Mücadeleleri”, Türk Kültürü Araştırmaları, XXI/1-2, 1984, ss.49-66,

AKA, İ.; Mirza Şahruh ve Zamanı, TTK yay., Ankara, 1994.

AKA, İ.; Timur ve Devleti, TTK yay., Ankara, 2000.

ALAN, H.; Bozkırdan Cennet Bahçesine Timurlular 1360-1506, Ötüken yay., İstanbul, 2007.

AMITAİ, R., "Mamluk Perceptions of the Mongol-Frankish Rapprochement", Mediterrranean Historical Review, Vol.VII/I, s.50-65.

ANDERSON, A.R., Alecander's Gate, Gog and Mogog, and the Inclosed Nations, Cambridge University Press, 1932.

ANDERSON, A.R.; "Alexander at the Caspian Gates", Transactions and Proceedings of the American Philological Association, Vol.59/1928, ss.130-163.

AYALON, D.; "Cerkes" (Memluk Period), Encyclopedia of Islam 2, Vol.II, Leiden, 1991, ss.23-24.

BALA, M.; "Çerkezler", MEB İslam Ansiklopedisi, C.III, İstanbul, 1981, ss.375386.

BALARD, M., La Romanie Genoise (XIIe debut XVe siecle), Vol.I, Genova, 1978.

BALARD, M.; "The Greeks of Crimea under Genoese Rule in the XIVth and XVth Centuries", Dumbarton Oaks Papers, Vol.49/1995, ss.23-32.

BALDWIN, M.W.; "Missions to the East in the Thirteenth and Fourteenth Centuries", A History of the Crusades, ed.K.M. Setton, University of Winconsin Press, 1985, ss.452-518.

BARANY, A., "The Last Crucesignatus Edward I and the Mongol Alliance", Annual of Medieval Studies at Central European University, Vol.16, s.1-22.

BARTHOLD, W.; İslam Medeniyeti Tarihi, Akçağ yay., Ankara, 2004. 
BARTHOLD, V.V.; "Islam na Çernom More", Soçineniye, Tom VI, Izdatel'stvo Nauka, Moskva 1966. ss.659-665.

BARTHOLD, V.V.; "Istoriko-Geografiçeskiy Obzor İrana", Soçineniye, Tom.VII, İzdatelstvo Nauka, Moskva, 1967, ss.31-225.

BARTHOLD, W.; "Suğdak”, MEB İslam Ansiklopedisi, C.XI, İstanbul 1979, ss.6-7.

BAYNER, H.; Istoriya Krımskih Gotov, Yekaterinburg, 2001.

BAYSUN, M.C.; "Azak”, MEB İslam Ansiklopedisi, C.II, İstanbul, 1979, ss.85-89.

BEAZLEY, C.R., The Dawn of Modern Geography, Vol. III, Oxford, 1906.

BOİS, Th.; Kurdistan, EI2, Vol.V, Leiden, 1986, ss.438-447.

CAFERÎ B. MUHAMMED EL HÜSEYNÎ, Târîh-i Kebîr (Tevârih-i Enbiyâ ve Mülukk), çev. İ. Aka, TTK yay., Ankara, 2011.

Chronographia Regum Francorum, T.III, Paris, 1897.

CiRKOVIC, S.M.; The Serbs, trans. by V. Tosic, Blackwell Publishing, 2004.

CLARK, L.V.; "The Turkic and Mongol Words in William of Rubruk's Journey (1253-1255)", Journal of the American Oriental Society, Vol.93/N.2, 1973, ss.181-189.

CLAVIJO, Embassy to Tamerlane 1403-1406, tr. G. de Strange, London-New York, 2005.

Corpus Scriptorum Historiae Byzantinae, editio emendatior et copiosior B.G. Niebuhri, Theophylactus Simocatta et Genesius, Bonnae, 1834.

COSMO, N. di; "Mongols and Merchants on the Black Sea Frontier in the Thirteenth and Fourteenth Centuries: Convergences and Conflicts", Mongols, Turks and Others, Eurasian Nomads and the Sedentary World, ed.R. Amitai and M. Biran, Leiden-Boston, 2005, ss.391-424.

DAŞ, A.; “Ankara Savaşı Öncesi Timur ile Yıldırım Bayezid'in Mektuplaşmaları", Türkiyat Araștırmaları Dergisi, S.15/2004, ss.141-168

DAŞ, M., "Saint-Denis Ruhbanının Kroniği Adlı Fransız Kaynağına Göre Niğbolu Savaşı", Tarih Incelemeleri Dergisi, C.XXVII/1, 2012, s.69-77.

DAŞ, M.; "Bizans Kaynaklarında Timur İmajı", Tarih İncelemeleri Dergisi, C.XX, S.2, Aralık 2005, ss.43-58.

DAVLETŞiN, G.M.; "Musul'manskoye Bogosloviye v Zolotoy Orde", Zolotoordinskaya Tsivilizatsiya, Vip.II/2009, ss.27-38.

DEVRIES, K., "The Effect of Killing the Christian Prisoners at the Battle of Nicopolis", Crusaders, Condottieri and Connon Medieval Warfare in Societies around the Mediterranean, ed. L.J. A. Villalon, D.J. Kagay, Brill Publishing, 2002, s.157-172. 
DEWEESE, D.; Islamization and Native Religion in the Golden Horde, Pennsylvania State UP, 1994.

DOWSON, C.; The Mongol Mission, New York, 1955.

EMECEN, F.M.; “İlk Osmanlı Kroniklerinde Osmanlı İmajı”, Prof.Dr. Ísmail Aka Armağanı, İzmir 1999, ss.27-36

FERRIER, R.; "Trade from the Mid 14th Century to the End of the Safavid Period", The Cambridge History of Iran, Ed.P. Jackson, Cambridge UP, 2006, ss.412490.

FISCHER, W.J.; “Ascensus Barcoch (I) A Latin Biography of the Memluk Sultan Barquq of Egypt (D.1399) Written by B. de Mignanelli in 1416", Arabica, Tome VI, Fasc.I/1959, ss.57-74.

FRANCESCO BALDUCCI PEGOLOTTİ, La Pratica Della Mercatura, ed. A. Evans, Cambridge, 1936.

GREGORY, T.E.; "Dyrrachion”, The Oxford Dictionary of Byzantium, Vol.I, Oxford UP, 1991, s.668.

HAMDANI, A., "Colombus and the Recovery of Jarusalem", Journal of the American Oriental Society, Vol.99/1, 1979, s.39-48.

IBN BATTUTA SEYAHATNAMESI, çev. A.S. Aykut, Yapı Kredi yay., İstanbul, 2010.

İNALCIK, H.; “Azak”, Encyclopedia of Islam 2, Vol.1, Leiden, 1986, s.808.

İNALCIK, H.; Osmanlı Imparatorluğunun Ekonomik ve Sosyal Tarihi, C.I, çev.H. Berktay, Eren yay., İstanbul, 2000.

İNALCIK, H.; Rönesans Avrupası, Türkiye İş Bankası yay., İstanbul 2012.

JACKSON, P.; "Medieval Christendom's Encounter with the Alien”, Historical Research, Vol.74/2001, ss.347-210.

JACKSON, P.; The Mongols and the West 1221-1410, Harlow, 2005.

JACOBY, D., "Camlet Manufacture, Trade in Cyprus and the Economy of Famagusta from the Thirteenth to the late Fifteenth Century", Medieval and Renaissance Famagusta, ed. M.J. K. Walsh, Ashgate Publishing, 2012, s.1-42.

JAHN, K.; “Tebriz: Doğu ile Batı Arasında bir Ortaçağ Kültür Merkezi”, çev. İ. Aka, Tarih Araştırmaları Dergisi, C.XIII/S.XXIV, 1979-1980, ss.59-79.

JEAN DE JOİNVİLLE, Bir Haçlının Hatıraları, çev. C. Kanat, Vadi yay., Ankara, 2002.

JOSAPHAT BARBARO, Anadolu'ya ve Iran'a Seyahat, çev. T. Gündüz, Yeditepe yay., İstanbul, 2009.

KAFALI, M.; "Deşt-i Kıpçak ve Cuci Ulusu”, Tarih Dergisi, S.25/1971, ss.179-188. 
KAFESOĞLU, İ.; Türk Milli Kültürü, Ötüken yay., İstanbul, 1998.

KAMALOV, İ.; Altın Orda ve Rusya: Rusya Üzerindeki Türk-Tatar Etkisi, Ötüken yay., İstanbul, 2009.

KANAT, S.; "Baybars Zamanında Memlûk-İlhanlı Münasebetleri”, Tarih Incelemeleri Dergisi, S.XVI/2001, ss.31-45.

KARPOV, S.P.; "Dokument1 po Istorii Venetsianskoj Faktorı Tana vo Vtoroy Polovine XIV v.", Priçernomor'ye v Sredniye Veka, Vip.I/1991, ss.191-216.

KARPOV, S.P.; "Ot Tanı v Urgenç: Eti Trudnıye Dorogi Srednevenov'ya", Sredniye Veka, Vip.LXI/2000, ss.217-224.

KERN, A.; "Der 'Libellus de Notitia Orbis' Iohannes III (De Galonifontibus) O.P. Erzbischofs von Sulthanyeh", Archivum Fratrum Praedicatorum, Vol.VIII/1938, ss. 82-123.

KNOBNER, A.; “Timur'un Yükselişi ve Batı'nın Diplomatik Cevabı”, çev. M.Ş. Yüksel, Türkiyat Araştırmaları Dergisi, S.18/2005, s.231-243.

KURAT, A.N.; Türkiye ve İdil Boyu, TTK yay., Ankara 2011.

LEWIS, B.; "Ifrandj mad", Encyclopedia of Islam 2, Vol.III, Leiden, 1986, ss.10441046.

LOCKHARD, L.; "European Contacts with Persia 1350-1737", Cambridge History of Iran, ed. P. Jackson, L. Lockhart, Cambridge UP, 2006, s.373-411.

LOCKHART, L., "The Relations Between Edward I and Edward II of England and the Mongol Il-khans of Persia", Iran, Vol.6, s.23-31.

MADGEARU, A.; "The Place of Crimea and of the Kerch Strait in the Strategy of the Middle Byzantine Empire", Il Mar Nero, V/2006, ss.193-208.

MALOWIST, M., "The Baltic and the Black Sea in Medieval Trade", Baltic and Scandinavian Countries, Vol.3/1937, s.36-42.

MANZ, B.F.; "Miranshah b. Timur", Encyclopedia of Islam 2, Vol.VII, Leiden, 1993, s.105.

MANZ, B.F.; "Timur ve Hâkimiyetin Sembolü”, çev. M.Ş. Yüksel, Tarih Incelemeleri Dergisi, Vol. XV/2000, ss.257-272.

MANZ, B.F.; Timurlenk, çev. Z. Bilgin, Kitap yay., İstanbul, 2006.

MARCO POLO, Dünyanın Hikâye Edilişi, C.I, çev. I. Ergüden, İthaki yay., İstanbul, 2003.

MARTINÇYUK, V.A.; "Rus i Litva v Socinenii Ionna de Galonifontibusa", Issledovaniya po Istorii Vostoçnoy Evropı, Vıp.IV, /2011, ss.79-88.

MAYENDORFF, J.; "From Byzantium to Russia: Religious and Cultural Legacy", Rome Constantinople Moscow, St. Vladimir's Seminary Press, 2003, s.113-130. 
MESERVE, M.; Türk, çev. M.T. Akad, April yay., İstanbul, 2011.

MíLET, H.; Les peres du Concile de Pise (1409), Melanges de l'Ecole Française de Rome, T.93/N.2, 1981, ss.713-790.

MIRGALEEV, İ.M.; Politiçeskaya Istoriya Zolotoy Ordl Perioda Pravleniya Toktamış Hana, Kazan, 2003.

MOĞOLLARIN GIZZLİ TARIHİ, çev. A. Temir, TTK yay., Ankara, 1995.

MOĞOLLARIN GIZZLİ TARIHHÇESİ, çev. M.L. Kaya, Kabalcı yay., İstanbul, 2011.

NIZAMÜDDİN ŞÂMÎ, ZAFERNÂME, çev. N. Lugal, TTK yay., Ankara, 1987.

O'RIORDAN, G.M.-BERINDEİ, M.; "Venise et la Horde d'Or fin XIIIe- debut XIV siecle", Cahiers du Monde Russe et Sovietique, Vol.29, Nu.2/1988, ss.243256.

ORHUNLU, C.; "Kefe”, Encyclopedia of Islam 2, V.4, Leiden, 1997, ss.868-870.

ÖZCAN, A.T., "Chronica Maiora'da Moğol İmajı", Tarih İncelemeleri Dergisi, C.XXVII/II, s.427-458.

ÖZCAN, A.T., "XVI. Yüzyıla Kadar Türkiye ve Türkmenya Adının Batı Dünyasındaki Kullanımı ve Sınırları", Türkiyat Mecmuası, C.22, s.63-82.

ÖZCAN, A.T., Moğol-Rus İlişkileri 1223-1341, Ege Üniversitesi Sosyal Bilimler Enstitüsü Basılmamış Doktora Tezi, İzmir, 2010.

ÖZCAN, A.T.; "XV ve XVI. Yüzyıllarda Karadeniz'in Kuzeyinde Doğu Mallarına Dair", Belleten, C.LXXV/S.274, 2011, ss.719-743.

ÖZTÜRK, Y.; Osmanlı Hâkimiyetinde Kefe 1475-1600, Kültür Bakanlığı yay., Ankara, 2000

PAPACOSTEA, S.., "Un Calator in Tarile Romane la İnceputul Veacului al XVlea", Studi Revista de Ístorie, Tom.18/1, 1965, s.171-174.

PAVIOT, J.; "England and the Mongols (1260-1330)", Journal of the Royal Asiatic Society, Vol.10/No.3, Nov. 2000, ss.305-318.

PAYDAŞ, K.; "Timur'un Gürcistan Seferleri”, Firat Üniversitesi Sosyal Bilimler Dergisi, C.16/S.1, 2006, ss.419-437.

PELLIOT, P., “A Propos des Comans”, Journal Asiatique, Tom.15, s.125-185.

PHILIPS, E.D.; "The Scythian Domination in Western Asia: Its Record in Histoy, Scripture and Archeology", World Archeology, Vol.4/No2, Oct. 1972, ss.129138.

POÇEKAEV, R.Yu.; "Russkiye Voyska v Zolotoordınskih Voennıh Kampaniyah", Zolotoordinskaya Tsivilizatsiya, Vip III/2010, ss.36-44. 
POLUBOYARINOVa, M.D.; Russkiye Lyudi v Zolotoy Orde, Akademi Nauk SSSR, Moskva, 1978.

PRAZNIAK, R., "Tabriz on the Silk Roads: Thirteenth Century Eurasian Cultural Connections", Asian Review of World Histories, Vol.I/2, 2013, s.169-188.

PREISER-KAPELLER, J., "Civitas Thauris: The Significance of Tabriz in the Spatial Frameworks of Christian Merchants and Ecclesiastics in the 13th and 14th Centuries", Politics, Patronage and the Transmission of Knowledge in 13th-15th Century Tabriz, ed.J. Pfeiffer, Brill Publishing, Leiden-Boston, 2014, s.251-299.

RİCHARD, J., "Le Debut des Relations entre la Papaute et les Mongols de Perse", Journal Asiatique, 137/1949, s.291-297.

ROEMER, H.R.; "Timur in Iran", Cambridge History of Iran, ed. P. Jackson, L. Lockhart, Cambridge UP, 2006, ss.42-97.

ROUX, J.P.; Türklerin ve Moğolların Eski Dini, çev. A. Kazancıgil, Kabalcı yay., İstanbul, 2002.

RUYSBROECKLİ WILLEM, Mengü Han'ın Sarayına Yolculuk, ed.P. Jackson, D. Morgan, çev. Z. Kılıç, Kitap yay., İstanbul, 2010.

SACY, S. de; "Memoire sur Une Correspondance Inedite de Tamerlan avec Charles VI", Memoires de L'Institut Royal de France Academie des Inscriptions et Belles-Lettres, Tome VI/1822, ss.470-522.

SCHEIN, S., "Gesta Dei per Mongolos 1300", The English Historical Review, Vol.94/373, s.805-819.

SCHMEIDER, F.; "Christians, Jews, Muslims-and Mongols: Fitting a Foreign People into the Western Christian Apocalyptic Scenario", Medieval Encounters, Vol.12/2, 2006, ss.274-295.

SIMON DE SAİNT QUENTIN, Bir Keşişin Anılarında Tatarlar ve Anadolu (12451248), çev. E. Özbayoğlu, Daktav yay., Antalya, 2006.

SWEENEY, J.R.; "Thomas of Spalato and the Mongols: A Thirteenth Century Dalmatian View of Mongol Customs", Florilegium, 4/1982, ss.156-183.

ŞEŞEN, R.; İslam Coğrafyacılarina Göre Türkler ve Türk Ülkeleri, TTK yay., Ankara, 2001.

TARDY, L.; "The Caucasian Peoples and Their Neighbours in 1404", Acta Orientalia, Tomus XXXII,/1, 1978, ss.83-111.

TAVKUL, U.; "Codex Cumanicus ve Karaçay-Malkar Türkçesi”, Türk Dünyası Dil ve Edebiyat Dergisi, C.15/2003, ss.45-81.

TAVKUL, U.; “Kumuk Türkleri”, Kırım Dergisi, C.13/50, 2005, ss.29-39.

The Opus Maius of Roger Bacon, Ed. J.H. Bridges, Volume I, London, 1900. 
TOGAN, Z.V.; "Vostoçno-Evropeyskaya Politika Timura", Zolotoordınskaya Tsivilizatsiya, Vip.III/2010, ss.209-220.

TOGAN, Z.V.; "Voyennaya Kampaniya Timura 1395 goda na Ukraine i Severnom Kavkaze", Zolotordinskaya Tsivilizatsiya, Vip.II/2009, ss.222-228.

TOMA METSOPSKI, TIMURLENK VE HALEFLERININ TARIHII, çev. G. Solmaz, Elips yay., Ankara, 2009.

UMNYAKOV, İ.İ., "Vneşnepolitiçeskie Svyazi Samarkanda s Gosudarstvami Zapadnoy Evropı", İstoriya Samarkanda, red. İ.M. Muminov, Taşkent 1969, s.173-195.

VERNADSKY, G.; Moğollar ve Ruslar, çev. E.B. Özbilen, Selenge yay., İstanbul, 2007.

WIXMAN, R.; "Lezgh”, EI2, Vol.V, Leiden, 1986, ss.729-730.

WOODS, J.E.; "Turco Iranica II", Journal of Near Eastern Studies, Vol.43/No.4, Oct 1984, ss.331-337.

YAKUBOVSKIY, A.Yu.; Altın Ordu ve Çöküşü, çev. H. Eren, TTK yay., Ankara, 2000.

YUVALI, A., Illhanlılar Tarihi I: Kuruluş Devri, Erciyes Üniversitesi yay., Kayseri, 1994.

ZEVAKIN, E.S.-Pençko, N.A., "Oçerki po İstorii Genuezskih Koloniy na Zapadnom Kavkaze v XIII i XV vv.”, İstoriçeskiy Zapiskiy, T.3/1938, s.72-129. 